\title{
EARLY IRON AGE BURIALS FROM EQUATORIAL GUINEA: THE SITES OF CORISCO ISLAND
}

\author{
Alfredo González-Ruibal, Llorenç Picornell Gelabert, Alba Valenciano Mañé
}

\begin{abstract}
During a survey undertaken on the Island of Corisco, also known as Mandji (Equatorial Guinea), in 2009, several sites of the Early and Late Iron Age were recorded. The most spectacular discoveries are three Burial Sites, the largest of which has yielded several intact tombs with many artefacts (axes, spears, anklets, bracelets, complete pots) radiocarbon dated to $410-640 \mathrm{AD}$. Objects, structures and ritual activities are similar to those documented in Early Iron Age cemeteries in Cameroon in recent years. The new data from Corisco contribute to change the image of the early iron-using societies in Equatorial Africa.
\end{abstract}

\section{Keywords}

Early Iron Age, Central Africa, Gulf of Guinea, Equatorial Guinea, Cameroon, equatorial forest, burial customs, ancient metallurgy, islands.

\section{Tombes de la Première Age du Fer en Guinée Equatoriale : le sites de l'île de Corisco}

\section{Resumée}

Grâce à une prospection archéologique menée à l'île de Corisco, aussi connu comme Mandji (Guinée Equatoriale), en 2009, plusieurs sites de l'Âge du Fer Ancien et Récent ont été découverts. Les trouvailles les plus spectaculaires sont trois sites avec des inhumations, le plus large desquels a livré diverses tombes assez bien conservées et datées par le 14C au 410-640 cal. AD. Objets, structures et activités rituelles sont pareilles à celles documentées récemment au Cameroun. Les nouvelles données de Corisco contribueront à changer l'image des premières sociétés métallurgiques en Afrique Equatoriale. 


\section{Mots clés}

Âge du Fer Ancien, Afrique Centrale, Golfe de Guinée, Guinée Equatoriale, Cameroun, coutumes funéraires, métallurgie ancienne, îles.

\section{Introduction}

Our knowledge on the African equatorial rainforest during the Iron Age increased significantly due to surveys and excavations during the last thirty years (Van Noten et al. 1982; Lanfranchi and Clist 1991; Clist 1989, 1995; Eggert 1992, 1993; Wotzka 1995). The prehistory of the area was virtually unknown until the beginning of a systematic campaign of surveys and excavations in the 1970s carried out by German, French and Belgian archaeologists. Despite the undeniable relevance of this research, data resulting from fieldwork were rarely detailed - in part due to geographical and environmental difficulties. Surveys and excavations allowed to define several archaeological groups, labelled with the name of the locality where the representative materials first appeared and basically known for their characteristic pottery types and their radiocarbon chronology (e.g. Clist 1995: 164-182; Wotzka 1995). The rainforest that covers most of southern Cameroon, Equatorial Guinea, Gabon, Congo, Democratic Republic of Congo and Central Africa has been traditionally portrayed as an area increasingly settled with villages during the Iron Age, belonging to small tribal societies of Bantu agriculturalists. They shared the vast territory with bands of hunter-gatherers, with whom they cohabited-as they do today-in master-client symbiosis, exchanging agricultural products for forest resources. The egalitarian communities of the rainforest were bordered by chiefdoms and archaic states which emerged during the late $1^{\text {st }}$ millennium $\mathrm{AD}$ in the lower Niger basin, the Upemba Depression and the Interlacustrine region (Connah 2001). These areas of so-called "complex societies" are much better known, since most efforts by archaeologists and historians in Iron Age Sub-Saharan Africa have focused on understanding the origins and development of those polities (e.g. McKintosh 1999; Connah 2001; Vansina 2004; Edwards 2007).

Large infrastructural works are starting to change this panorama. Archaeological research related to the Chad-Cameroon pipeline (Lavachery et al. 2005) and other construction works, such as roads, have brought to light a wealth of extraordinary findings in southern Cameroon, which compel us to review some of our tenets about the peoples of the equatorial rainforest during the Iron Age (Olisly 2006; Meister 2007, 2010; Meister and Eggert 2008). One of the most relevant findings is a series of tombs 
and burial sites dated between the $50 \mathrm{BC}$ and $550 \mathrm{AD}$ (Eggert et al. 2006: 281-285; Gouem Gouem and Lavachery 2006; Eggert et al. 2008; Meister 2010; Meister and Eggert 2008). These cemeteries, of which the most remarkable are Mpoengu, Campo, Lobethal and Akonétye, are characterized by pits with complete pots and graves in which numerous iron objects were deposited, including axes, hoes, spearheads, arrowheads, bracelets and anklets, and currency items (Meister 2010). The amount and diversity of iron implements has little to do with the archaeological record known hitherto, which was rather poor and monotonous. Although pits filled with artefacts are known for the area prior to this period (Lavachery et al. 2005; Gouem Gouem and Lavachery 2006), metal deposits seem to appear quite suddenly, as nothing equivalent exists before $50 \mathrm{BC}$. The craftsmanship of the artefacts is usually excellent. Given the outstanding accumulation of wealth that some of these deposits imply, it can be safely argued that hierarchical polities emerged at that time in southwestern Cameroon with a striking capacity of expansion. This adds yet another dynamic area of chiefdom formation south of the Sahara and the first to emerge in Equatorial Africa.

However, the tombs of southern Cameroon do not only furnish data about a previously unknown ritual phenomenon and about social complexity. Due to the rich offerings associated to the tombs, we are now more able to explore the symbolic world of the Iron Age communities and their social practices, something that will have to be done with the help of the rich anthropological and ethnohistorical sources of Central Africa. It is therefore a qualitative difference that this new archaeological record brings, when compared with the hardly expressive data available so far.

When they first appeared, the sites of southern Cameroon were unique in Equatorial Africa. In August 2009, however, we had the chance to conduct an archaeological survey of the Island of Mandji (also known as Corisco), in the estuary of the river Muni, between Equatorial Guinea and Gabon, which provided more contexts and findings related to the cultural phenomenon documented in Cameroon. In 2008, two of us (LPG and AVM), who at the time were employed at the Spanish Cultural Centre at Bata, were showed intriguing archaeological artefacts discovered made during the construction of an airstrip in Mandji. The most striking finds were several complete decorated vessels of different sizes and shapes. A first visit to the place allowed us to check the extension of the area covered by archaeological remains and prompted a more systematic survey, which was carried out in 2009 with the generous financial support of the Spanish Cultural Centre at Bata, depending on the Spanish Cooperation Agency 
(AECID). The aim of this article is to describe the findings of our 2009 survey and show how the cultural tradition documented for the Early Iron Age in southern Cameroon can be extended almost two hundred kilometres to the south.

\section{The archaeology of Equatorial Guinea}

Archaeological work in Equatorial Guinea has been very limited so far. During the time of the Spanish colony (1843-1968) most of the work was carried out by Catholic missionaries and their research focused basically on the Island of Bioko. Father Martín del Molino $(1965,1989)$ was able to delineate the archaeological sequence of the island from the mid- $1^{\text {st }}$ millennium AD to the Spanish occupation. The techno-typological groups that the missionary singled out are very peculiar to the island and bear little resemblance with other prehistoric cultures in the region, including the sites in the Muni estuary, where our work has been carried out. From the findings of Martín del Molino, it seems that iron in Bioko arrives tardily and does not become generalized before the early $19^{\text {th }}$ century (Clist 1998), despite its proximity to core areas of very early iron production in Cameroon and Gabon (Holl 2009: 418-420). Polished stone implements prevail throughout the entire archaeological sequence. The culture that was explored in more detail was the one called Carboneras, whose eponymous site was discovered in the late 1950s (Panyella y Sabater 1959). None of the many sites belonging to this culture yielded any iron implement or traces of metallurgical activities whatsoever. Radiocarbon dates place Carboneras in the second half of the first millennium AD, between the $6^{\text {th }}$ and $11^{\text {th }}$ centuries $\mathrm{AD}$ (Clist 1991: 161; Clist 1998). Carboneras is divided into three phases (early, middle and late), the last of which is characterized by pits filled with decorated pottery sherds, grinding stones, polished axes, charred palm endocarps, and other elements. Clist (1998) has noted some striking similarities between certain pottery types of the Carboneras tradition and those of the Gabonese Groupe II, which has roughly the same chronology (ca. 600-1000 AD). The apparent contacts existing between Bioko and the Gabon estuary during the early Iron Age make even more bewildering the late acceptance of iron in Bioko, as traces of iron production exist from the second half of the $1^{\text {st }}$ millennium BC in the former French colony (Clist 1995: 182-184). A Later Iron Age period (Buela/Bolaopí traditions) was also identified by Martín del Molino through stratigraphic, typological and radiocarbon evidences (ca. 1000-1500 AD) (Cf. Clist 1998). 
Ramón Perramón (1968) was another missionary with an interest in archaeology. He explored the continental part of Equatorial Guinea and conducted surveys in the Muni estuary, including the Island of Mandji, where he discovered two Iron Age sites: one under the camp of the colonial army and the other one in the village of Ulato, both in the south of the island. Perramón defined the Iron Age pottery tradition of the estuary, but was not able to specify particular phases or to propose a sequence as Martín del Molino had done for Bioko. Although perhaps too hastily, Bernard Clist (1998) actually placed all of Perramón's pottery finds in the Muni within the Late Iron Age group of Angondjé, which is dated in Gabón between 1000 and 1500 AD.

After the end of the colony, archaeological work was interrupted until 1985. In that year, Bernard Clist carried out a field season in the continental part of Equatorial Guinea. He conducted limited excavations in a shell midden in Ayene, a promontory overlooking the Muni estuary. The site was radiocarbon dated to the $13^{\text {th }}-14^{\text {th }}$ century $\mathrm{AD}$, that is the Late Iron Age (Angondjé group: Clist 1998). He also discovered two other sites, Akom and Punta Eviondo (Clist 1987, 1998), close to the continental capital-Bata. The site of Akom had pits filled with charcoal, charred palm endocarps and pots, like those of Carboneras in Bioko. The site of Carboneras itself was reexcavated (de Maret and Clist 1987). Charcoal samples from Carboneras (another, later, site studied by Martín del Molino) were radiocarbon dated and offered more chronological precision to the sequence proposed by Martín del Molino. Archaeological work in Equatorial Guinea, nevertheless, was not resumed after the preliminary season of 1985. Clist's research in the coastal area of Gabon, though, has been very useful to shed light on the archaeological record of southern Equatorial Guinea and particularly on its Iron Age. Unlike Gabon and Cameroon, Equatorial Guinea has not provided any Holocene remains to date that can be unambiguously dated before the early- $1^{\text {st }}$ millennium AD. This situation will certainly change as archaeological research proceeds in the country.

The last archaeological intervention in Equatorial Guinea (before our survey) took place in 1998: Julio Mercader and Raquel Martí explored the area of Monte Alén and excavated several sites of the Middle and Late Stone Age (Mercader and Martí 1999). No later periods were investigated.

The situation of Equatorial Guinea, from an archaeological point of view, contrasts with that of other Central African countries, which have benefitted from extensive research during the last three decades. With our work in the Muni estuary, we 
expect to contribute to filling the archaeological gap. The prospects are good, as we will see.

\section{The Island of Mandji}

The Island of Mandji is located at the entrance of the Muni estuary, which acts as a frontier between Equatorial Guinea and Gabon (FIGURE 1). We use the local name given by the current inhabitants of the island (the Benga), rather than the name given by the Portuguese explorers-Corisco.

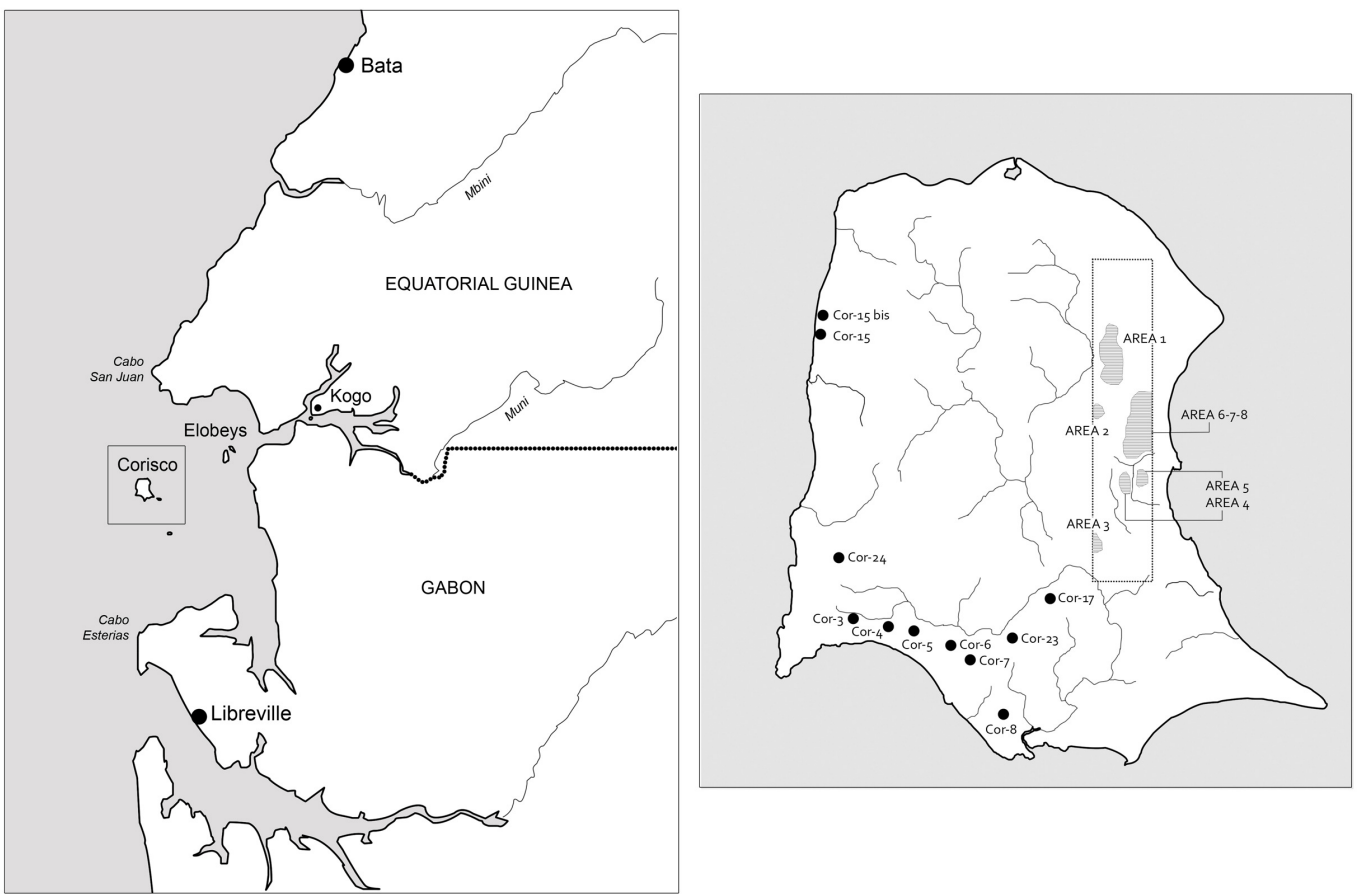

Figure 1. Area of the Muni and Gabon estuaries and map of Mandji with Iron Age sites discovered during the 2009 survey.

Mandji is in fact closer to Gabon, from whose northern coast is only separated by $24 \mathrm{~km}$. The island occupies 15 square kilometres and, despite its exiguous size, it is the largest in the estuary. Its longest axes are $6 \mathrm{~km}$ north-south and $5 \mathrm{~km}$ east-west. It is predominantly flat: the highest point is a rocky promontory (Elongo) of 35 meters located in the northern part of the island; the rest of the coast is surrounded by highly siliceous sand beaches. In the 1940s, Mandji was covered by second-growth forest (24\%) and mangroves (60\%), which are virtually impenetrable (Unzueta y Yuste 1945: 91). There are, however, several grasslands (8\%), the largest of which are Elua (15 hectares), in the southeast corner, and Nanda (20 hectares), in the centre-east. Only 1\% 
of the island was cultivated during the Spanish colony, an area which is about the same today. There are many small rivers and rivulets that flow into almost every direction, except the eastern coast. The most important stream is the river Lembue that flows from north to south. Associated to this river there exist several small lakes, ponds and swamplands which, along with the river Lembue, divide the island roughly into two halves (east and west).

The island of Mandji was discovered by the Portuguese during their exploration of the African coast in the late $15^{\text {th }}$ century. The Portuguese called the island Corisco ("lightning") and described it as unpopulated and mostly useless. However, the growth of the Atlantic slave trade gave unexpected relevance to the place, which became the object of disputes between the Dutch, the French and the Portuguese (Nerín forthcoming). After the end of the slave trade, the island became a key base for the Europeans to trade with the continent, due to its strategic location near the mouth of the rivers Muni and Gabon. Thus, Mandji witnessed the establishment of several outposts by German, British, French and Spanish merchants. The island was officially incorporated into the Spanish Crown in 1843 (Unzueta y Yuste 1945: 73), in whose possession it remained until the independence of Equatorial Guinea in 1968. According to local lore, the Benga, a Bantu group that was being pushed away from their lands in continental Guinea due to fights with other communities, arrived to Mandji around the $18^{\text {th }}$ century. The Benga seem to corroborate the European version of the history of the island, since they claim that when they reached Mandji there were only a bunch of Portuguese sailors. Although this point has to be further explored, the cut in the indigenous history may preclude the possibility of using ethnohistorical sources to complement the archaeological information pre-1700.

During the last years, the island has suffered the developing impetus of the Equatoguinean government, which is investing part of the oil revenues of the country in infrastructural projects (roads, ports and airports). The idea is to turn Mandji into a tourist destination, for which the construction of several hotels, golf courses, yachting harbours and promenades have been planned. These developments will affect a large part of the island (maybe as much as $30 \%$ of its surface). By far, the infrastructure that is having a heavier impact is the airport. Its construction, parallel to the eastern coast has implied extensive clearings and soil removal that affect $10 \%$ of the island's surface. The runway, which has been designed to give service to long-haul flights, will stretch for $2.5 \mathrm{~km}$. Related to the construction of the airport is a gravel road that communicates 
the southern edge of the airstrip with the western coast of the island. Although a disaster from an ecological and cultural point of view, airstrip and road provided two excellent transects that allowed us to sample a relevant portion of the island. In fact, our survey was mainly aimed at the places that have been more severely touched by construction works, because in those areas where the forest has not been felled and the topsoil removed, it is extremely difficult to discover any archaeological remains. This explains that almost $90 \%$ of all prehistoric scatters recorded during our survey were in the mentioned transects (cf. Figure 1). Two scatters were found in a well-trodden path, which was being eroded by the beach (Cor-15 and Cor-15b). A third prehistoric site outside the transects was the one identified by Perramón (1968) in the grounds of the camp of the colonial army. We recorded the point but could not find any single item, due to the vegetation.

Our work consisted in field walking systematically the areas exposed during construction works. In the area of the airport, we walked in four parallel lines, following the N-S orientation of the runway (which had not yet been asphalted), and covered the entire terrain affected by the works. The most notable findings (including all metal objects) were georeferenced and artefact scatters delimited with a handheld GPS. We consider to have identified all visible sites in the area of the airport. We also walked the entire road, from the airport to the west coast (Magane-Sai), paying attention to the sides where the earth has been removed. The resolution of our survey here was also very high, although perhaps not of the $100 \%$ as in the airport. In total, 17 prehistoric sites were discovered during the three-week survey. The distribution of the sites is as follows: 8 loci along the airport road, 6 loci on the airport area, 3 loci elsewhere. It has to be taken into account that some of the loci identified on the road may probably belong to the same site, especially if we consider the wide surface occupied by some of the sites of the airport. Thus, Cor-15 and Cor-15bis might be just one settlement and the same can be said of Cor- 6 and Cor-7. The limits of the sites found along the road are difficult to define precisely. The points that appear in the map only show the areas of maximum accumulation of finds.

The most spectacular discoveries took place in the airport area. It was there where the entire vessels that were first shown to us had turned up. Through our survey and interviews with neighbours, engineers and workers involved in the construction of the airport, we managed to ascertain with some precision the places from which the vessels had been recovered. Unfortunately, two different sites furnished the same kind 
of pots. It is therefore impossible to tell with certainty which pots are to be associated with each particular site. In any case, the data gathered during our research made clear that there are at least three large necropolises from the Iron Age. The rest of this article will be devoted to describe these sites.

\section{The Iron Age cemeteries of Eastern Mandji}

The airport was the first place to be surveyed and the one that yielded the most relevant findings. The artefact scatters of the airport, which stretch through thousands of square metres, were described and recorded as "areas". We defined eight areas from north to south and counter-clockwise. Besides, we also gave a correlative number to every area, within the site inventory of Mandji-Corisco (Cor-001, etc), which includes both historical and prehistoric sites and artefact scatters. Finally, each of the burial sites was named correlatively. Thus, Burial Site 1 is Area 1 (within all the areas of the airport) and Cor-010 (within all the sites of Mandji-Corisco); Burial Site 2 is Area 3 and Cor012, and Burial Site 3 is Areas 6 to 8 (the site was subdivided, see below) and Cor-020.

It is important to note that no open archaeological excavations or test pits were carried out: all findings come from surface collection during our survey, the collections of islanders, or the cleaning of the cuts left by the diggers. All contexts, then, were already somewhat exposed or altered when we documented them. For this reason we did not sieve the sand or take palaeo-environmental samples (only 14C samples in the better-preserved contexts). A proper archaeological excavation of the intact areas is planned: it will be carried out in those parts of the BS2 and BS3 which are still untouched, but are prone to erosion or other destructive agents. These excavations will allow us to obtain fine-grained stratigraphic, archaeological and palaeo-environmental data which will help to contextualize and interpret the finds presented in this article.

\section{-Burial Site 1 (BS 1)}

This Burial Site occupies around 5 hectares and it is oriented N-S. For sampling purposes, we divided the area into two zones ( $\mathrm{E}$ and $\mathrm{W}$ ), with the road that passes through the middle of the airstrip — from north to south - as the limit between the two. The western half furnished many more materials than the eastern one, including all notable metal finds. At this point, it is difficult to gauge the extent of the damage provoked by the construction works, without carrying out test pits. These could not be carried out due to the limited time available and the large number of sites and surface 
finds that had to be recorded, but we intend to conduct an excavation here in our next field season. All the terrain of the airport was levelled, but the southern part seems to have been dug deeper than the northern part, where BS 1 is. Thus, whereas in the other two cemeteries it is possible to see cuts in the dunes exposing layers up to 3 meters deep, in the northwestern part there are no such cuts or they are much lower $(0.5$ meters in Area 2). However, the immense amount of archaeological materials that carpet the surface occupied by BS 1 leads one to think that the damage has been very severe. It is possible that the possible graves and pits of this site appeared closer to the surface than in the other two cemeteries, a fact which would have led to their complete (or almost complete) destruction.

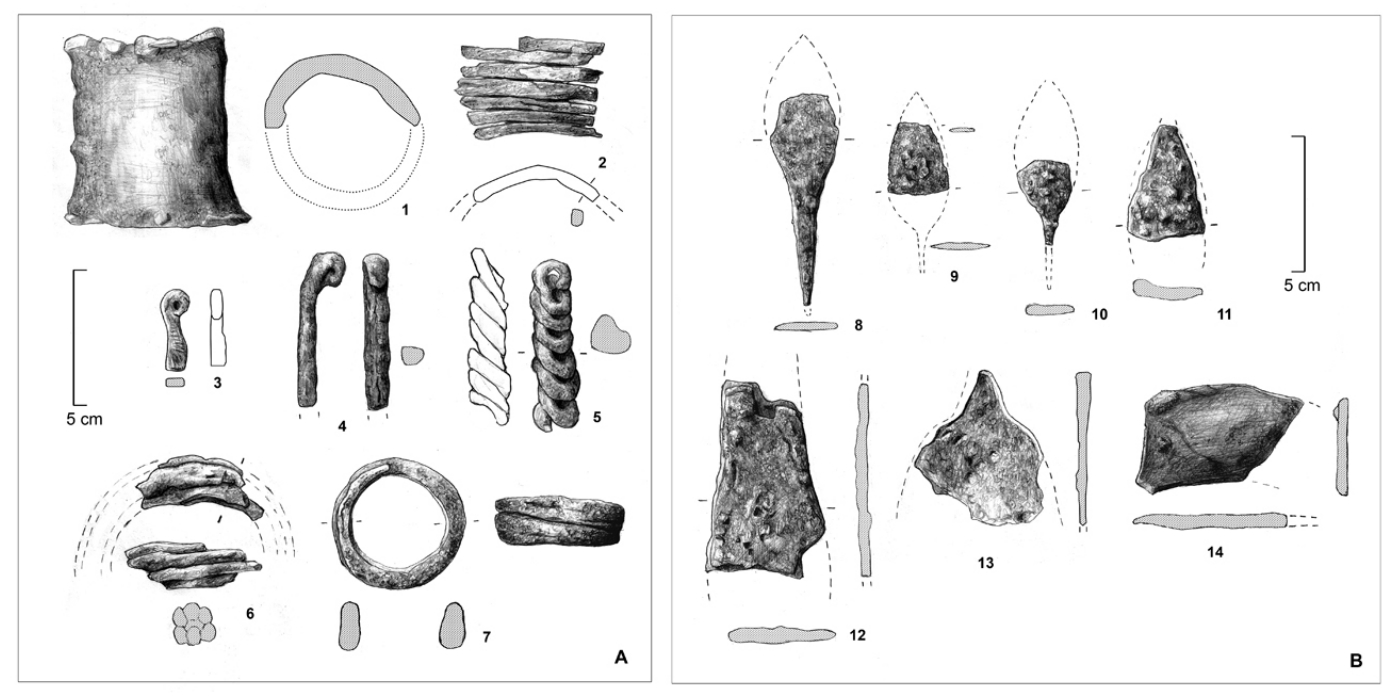

Figure 2. Adornments (A) and weapons (B) from Burial Site 1.

Metallic finds were abundant, but not as much as in Burial Site 3. On the contrary, pottery is plentiful. The metal inventory (FIGURE 2) differs from the other burial site that yielded an important amount of finds-BS 3. Out of 18 identifiable iron artefacts collected in BS 1, 60\% were adornments, 30\% weapons and the remaining $10 \%$ probably tools. Only a possible fragment of a sickle or knife (cf. Meister 2010: fig. 5) was identified. No axe or element of currency turned up. This is in clear contrast with BS 3, where these items prevail, as we will see. Regarding adornments, the most striking specimens are two complete iron torques and a fragment from a third one (FIGURE 3). More or less similar collars are known in Gabon, Congo and Cameroon for the last five centuries, but they were made in bronze or brass, not in iron. Bracelets made of iron rods have been used until very recently (Tessman 2003 [1913]: 217-260). 
The other adornments (all in iron) are a thick small ring, possibly used as a hairgrip; two thick pins, which might have been used as hair ornaments (like among modern Mangbetu?); a chain (from a wristlet or necklace?), and a plain bracelet made with a thick sheet of iron. Plain bracelets made in brass were used by the Fang in Gabon, as opposed to decorated bracelets worn by women (Perrois 1985: 185). We date the metallic artefacts in the Iron Age, as not a single post-contact item (such as wheelturned pottery, glass or glass-beads) has been located. Apart from iron objects, the site has also yielded many small slags and iron ore (hematite), but no trace of any tuyere. 

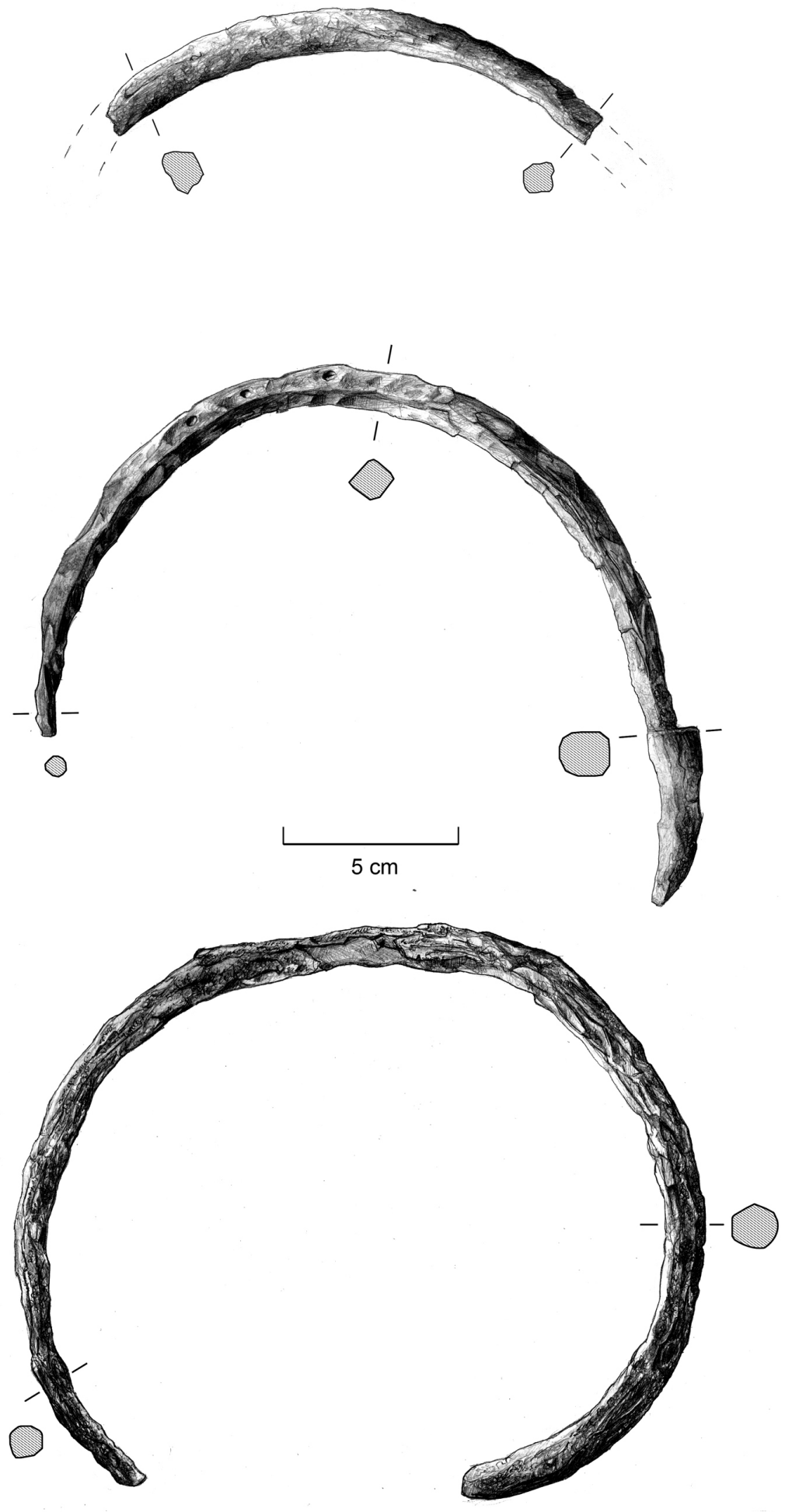

Figure 3. Torques from Burial Site 1. 
Most pottery sherds appear very fragmented and eroded (the site had been exposed to torrential rains for two years when we conducted our survey), but a striking array of decorations and shapes can be identified (FIGURE 4). There seems to be at least two wide periods that can be identified through pottery: Early and Late Iron Age. To the first period belong a particular type of everted pointed rim that thickens at the end and shows a vertical face to the outside, often decorated with incision and impression. It shows some resemblance with the productions of Carboneras in Bioko, so it might be dated to the Early Iron Age. Besides, it is very abundant in Mandj in BS3, a site where an Early Iron Age phase has been confirmed (see below). Among the decorations of the Early Iron Age we have reticular, herringbone or zigzag patterns and deep, parallel incisions (grooves). Sometimes, the incised lines have been decorated on top with simple/comb impression or deeper incisions. A similar technique has been documented in Early Iron Age sites of southern Cameroon, although the overall result is somewhat different (Meister and Eggert 2008: fig. 5, 4 and 7). There are also some sherds decorated with a wavy pattern, made with a comb. Wavy patterns are characteristic of the Early Iron Age in Gabon (Clist 1995: 168). Comb impression is frequent and has been also attested in "Groupe II" sites from the Early Iron Age (Peyrot et al. 1990). The scarce fragments decorated with roulette can be assigned to the Late Iron Age (Clist 1989: 87-86). To this period also belong thick, diamond-shaped friezes (FIGURE 4, n. 8) and incised horizontal lines over-impressed with dots (FIGURE 4, n.6). Rims of these period are thinner and very often slightly everted. Diagnostic elements of the Late Iron Age are the pedestalled bottom (Clist 1998) and the decorated lid knobs-lids are also a very typical element of the Late Iron Age (FIGURE 5). These prehensile buttons show a great diversity: similar knobs were documented by Perramón (1968) in different sites of the Muni estuary. The total absence of clay beads, which are very characteristic of the Late Iron Age (Clist 1995: 168), is surprising. We have to take into account, though, that from all sites recorded in Mandji, only one clay bead has been located (Cor-17). Cor-17 also yielded typical Late Iron Age materials similar to those of BS1, including pedestalled bottoms and decorated lid knobs. It is worth mentioning that many sherds show the use of ground hematite as temper. 


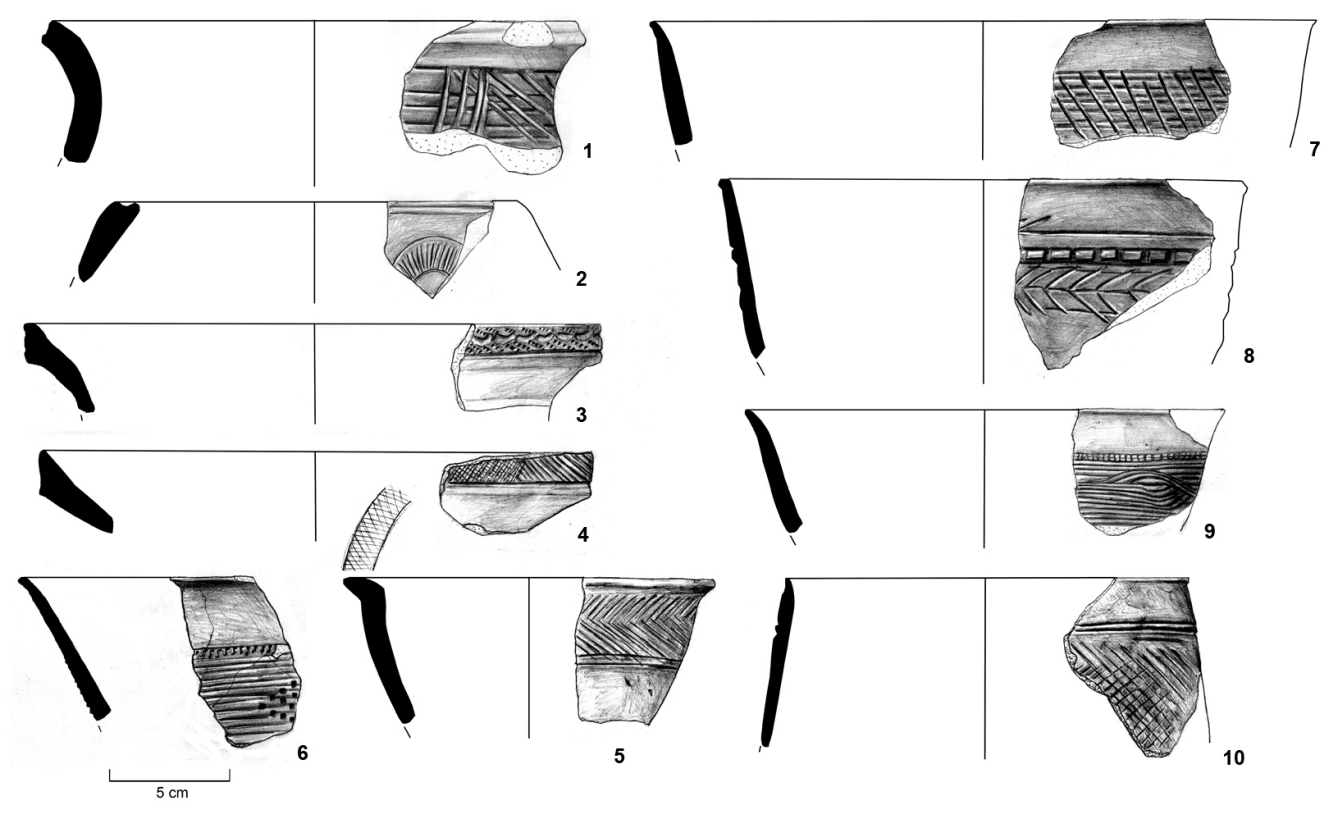

Figure 4. Decorated rims recovered from the surface of Burial Site 1. 1-5: Early Iron Age. 6-10: Late Iron Age.
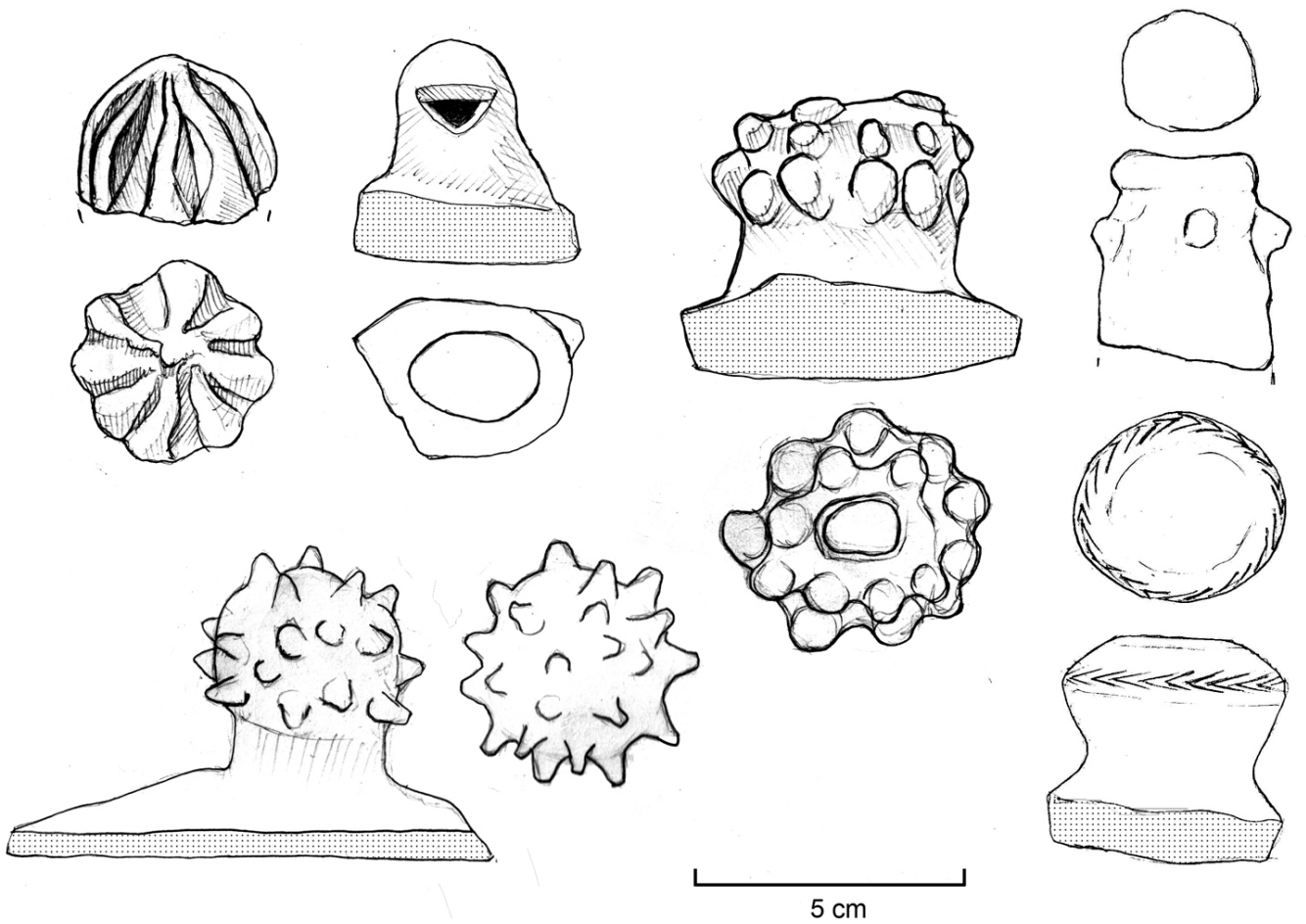

Figure 5. Decorated lid knobs from Burial Site 1. Late Iron Age.

Pottery, then, seem to support two different phases. To which of these phases do the metal artefacts belong? We think that they should be placed in the Late Iron Age, due to 
the important typological differences between the metal inventories of BS1 and BS3. In BS1 no flat hoes or axes have appeared, whereas in BS3 (like in the Early Iron Age Cameroonian burials) there are no solid torques.

Finally, our reasons to consider that there was a burial zone in Area 1 are the good preservation and high number of metallic elements and the fact that adornments are particularly abundant. Iron artefacts are rarer in other sites, even in sites that have yielded large numbers of pottery sherds, and in these places adornments are rarer or nonexistent. Interestingly, Cor-011 and Cor-17, which we identified as settlements, furnished only an iron element each, and in both cases it was a tool (adze). According to the engineer in charge of the works, during the excavation of the area of the runway a large number of iron collars and bracelets turned up. That there was a burial site (or several) in Area 1 does not mean that the entire area was a cemetery. It is more plausible that we are dealing with a large, scattered village (or rather, several successive villages established in the same place). The settlement seems to have had different activity areas, including burials and metallurgical workshops. As in most traditional Sub-Saharan societies, the distinction between cemetery and the rest of the village was in all likelihood absent. In the next field season, test pits will be carried out to define the different activity areas as well as the chronological sequence.

\section{-Burial Site 2 (BS 2)}

This is the burial site that was probably least affected by the construction works and, at the same time (or precisely because of this), the area that furnished fewer materials. The morphology of the dune that the site occupied is still perfectly visible (FIGURE 6) and some very fragmented and eroded sherds and lithics appear around the cut made by the diggers, both on top of the dune and at its base. The original dune overlooked the river Lembue, which is located immediately to the west. According to the engineer in charge of the excavation, after the dune was carved out, it was possible to see very clearly the different layers, due to differential soil colour and texture. A line of ash with many archaeological materials in situ was apparently visible. The complete destruction of all archaeological levels within the area excavated for the runway and the pristine condition of the rest of the dune where the site is makes it very difficult to calculate the total surface occupied by the archaeological site. In any case, it seems that it was smaller than the other two, perhaps a third of Burial Site 1. The archaeological materials that we gathered are scarcely indicative of the importance of the site: a few dehydrated pieces of 
chert (including a blade and two flakes), which show a powdery look, and mostly nondiagnostic sherds, although a handful of decorations and rims did appear, including a fragment that can be dated to the Late Iron Age - Angondjé tradition (FIGURE 7).

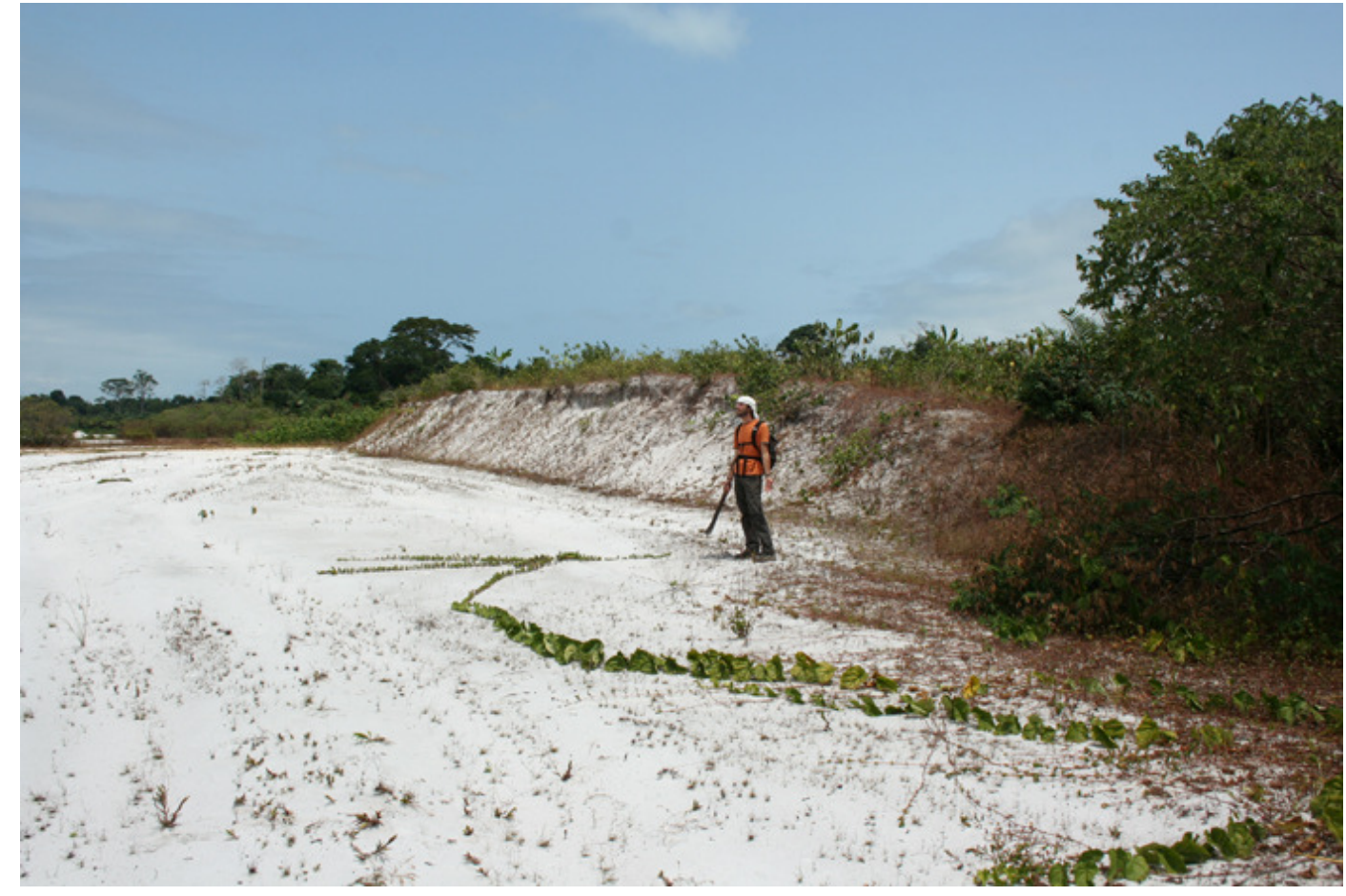

Figure 6. The dune where Burial Site 2 was established cut by the diggers during the levelling of the airstrip.
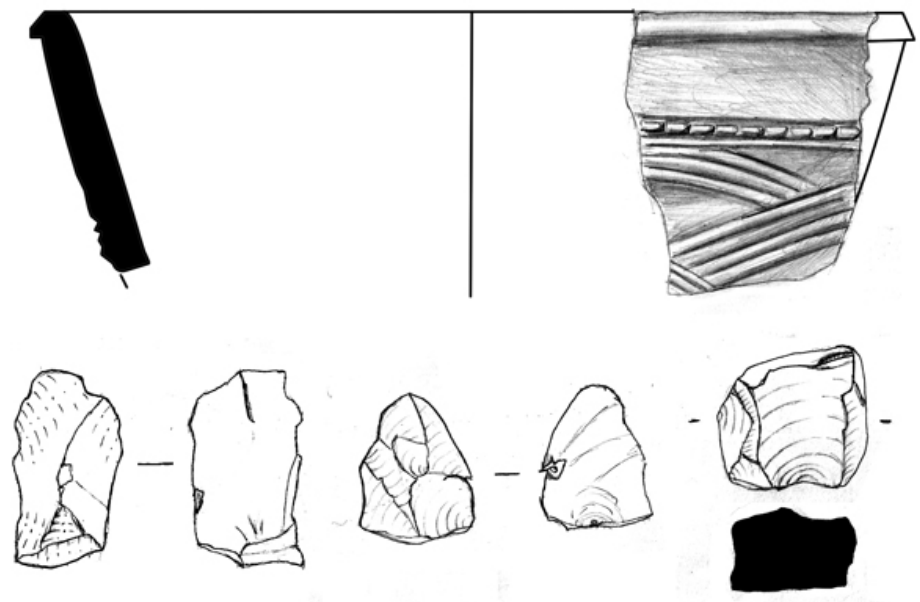

Figure 7. Surface materials from Burial Site 2. Angondjé-style decorated rim and lithics. The blade to the left is made in quartzite. The other two are dehydrated chert. 
The reason why we consider a burial site to have existed in this area is that several islanders (including construction workers at the airport) coincided in pointing this place as the source of the largest amount of complete pots. Although this is not an unequivocal sign of a ritual area (especially for later periods), the contexts in which intact vessels appear in the Early Iron Age of the region indicate a burial or other ritual context (Peyrot et al. 1990). Our own findings in Burial Site 3 also suggest that we are dealing with ritual deposits. Our informants pointed at a very specific place, 60 metres to the east of the extant dune, so it is possible that the burials were located there, whereas the line of ash about which the engineer told us might belong to a settlement area. According to our informant's description, the way the whole pots were deposited recalls that of some southern Cameroonian sites, such as Campo (Meister and Eggert 2008) and Yaoundé-Obogo (Meister 2010: 239-240). Nevertheless, in Mandji (as in the Gabonese sites: Peyrot et al. 1990) all pots apparently were buried upright and not downturned, as in Cameroon. We were able to locate several of the vessels dispersed among different households in Mandji and drew them (FIGURE 8).

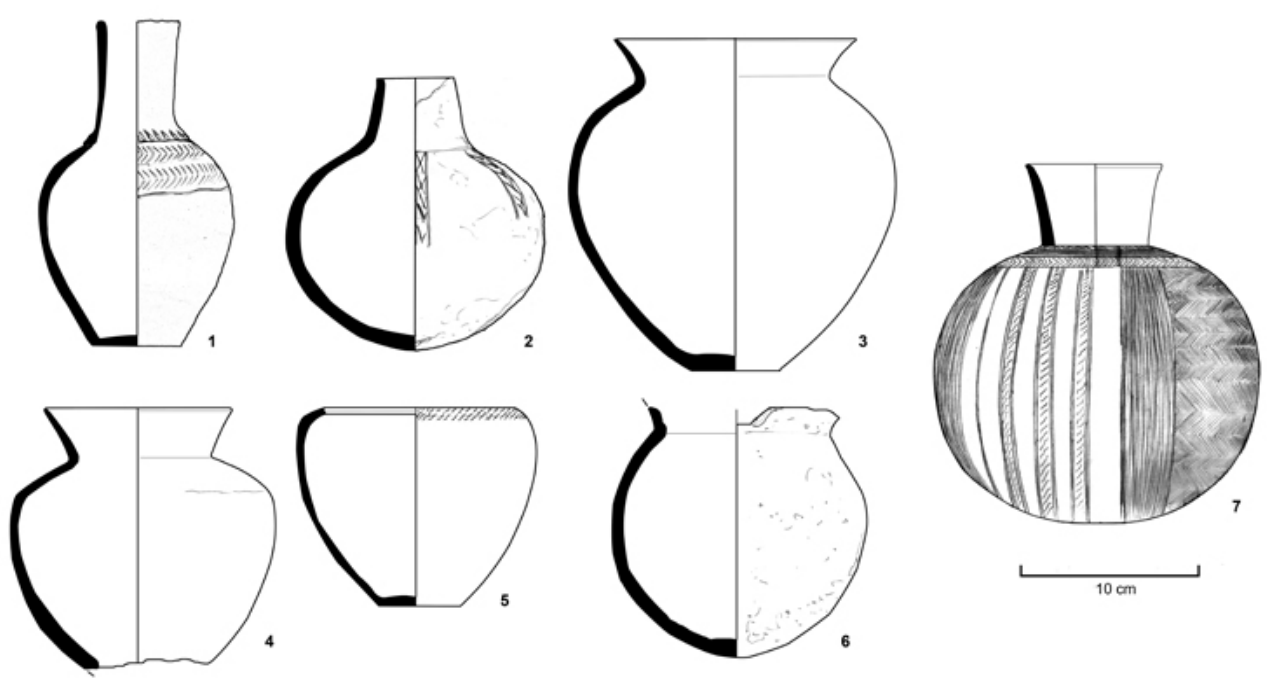

Figure 8. Complete pots from Burial Site 2.

We suspect, however, that some of the pots may come from Burial Site 3, where we found in situ pots similar to those in possession of the islanders. We will describe the pots here, with the caveat that not all of them necessarily come from the site. The nine complete pots that we have had the chance to observe are of small size (max. height: 10$15 \mathrm{~cm}$; max. width: 12-20 cm). This can be due to conservation issues, as larger pots 
tend to fragment more easily and for that reason were not collected by the neighbours; however, some of the pots recovered in what seems to be an equally ritually context in Sablières (Gabon estuary) are equally small (Peyrot et al. 1990: 489-490, see below). Something that cannot be attributed to mere chance is the fact that all complete pots have simple rims, in contrast with the sometimes complex rim morphology of other, fragmented, pots not found in burial or pit contexts. The predominance of bottle-shaped pots is also very characteristic: it is probably related to religious beliefs and burial rituals that might have been involved the use of alcoholic beverages. Bottles or fragments of bottles have not appeared in Iron Age sites of Mandji other than Burial Site 2 and 3. The decoration of the pots is predominantly incised, with parallel lines or combinations of parallel and oblique lines and herringbone patterns, but there is also comb impression (FIGURE 8, numbers 5 and 7). Typologically, the pots are very similar to those recovered in Sablières, in terms of shape, size and decoration (Peyrot et al. 1990: 489-490), although the lavishly decorated bottle (n. 7) and the only pot with inverted rim (n. 5) have no known parallels. A type which is very characteristic and appears both in Sablières and Mandji is a bottle with a spherical body into which an inverted truncated cone is inserted as a neck (FIGURE 8, number 7). Sablières is included in Clist's "Groupe II", which is dated from 600 to 1000 AD. Curiously, Peyrot et al. consider the Sablières' pot as typologically isolated in the Gabonese Iron Age and propose, instead, parallels in Bioko's pottery of the Carboneras period, which has the same date as that proposed for Sablières. This would reinforce the idea that we are in front of a characteristically coastal phenomenon, which explains both the similarities between coastal Cameroon, Guinea and Gabon, and the differences with their respective hinterlands.

In sum, as in BS1, we have here both Early Iron Age and Late Iron Age materials, although the former are apparently much more abundant than the latter. The lithic materials could be dated perhaps to the Late Stone Age.

\section{-Burial Site 3 (BS 3)}

This is the most interesting Burial Site of the three recorded due to the relevance of the findings and the appearance of graves in context, and not just isolated or decontextualized finds. As in the case of BS 1, the orientation of the site is N-S. The maximum length of the N-S axis is 550 meters and that of the E-W axis is $160 \mathrm{~m}$. The total surface originally occupied by this site was at the minimum 5 hectares, of which as 
much as $70 \%$ has been totally destroyed. Still, 1.5 hectares have been saved, for unknown reasons, by the diggers. We say for unknown reasons because the part that has not been excavated protrudes from the line that delimited the area scheduled for levelling, as it is clearly observable on the map (FIGURE 9). Further to the east, the earth has not been touched and there might be burials as far as the beach, which is about 75 meters away from the tombs. This would add an untouched strip of land of 1.5 hectares to the total surface of the cemetery. Findings appear $50 \mathrm{~cm}$ below the surface and continue for about $75 \mathrm{~cm}$, that is, $125 \mathrm{~cm}$ from the earth surface, although depth varies slightly from place to place. In the northern part, tombs appear to be closer to the surface $(30-40 \mathrm{~cm})$. The entire site lies on a large, fixed dune which is delimited by rivulets and swampy terrain on three of its sides (north, south and west) and by the beach on the remaining side (east). Given the large size of the site, we decided to divide it into three areas during the survey: Area 6, 7 and 8.

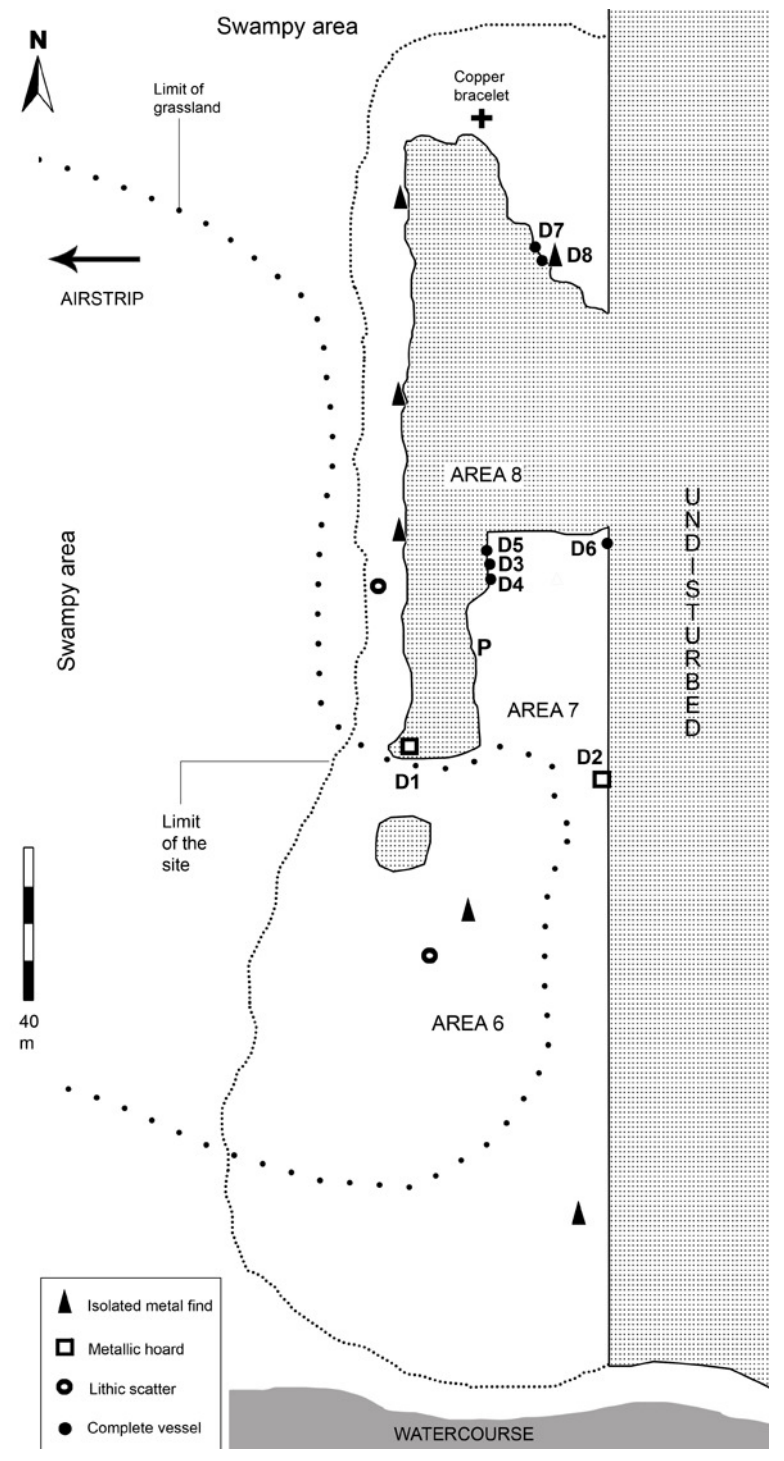

Figure 9. Map of Burial Site 3.

Area 6 was the one most affected by the diggers, which cut the dune two metres deep. This part of the site is in all likelihood completely destroyed. Pottery sherds, broken to very small pieces and heavily eroded, appeared on the surface, but in quantities not comparable to BS 1 or the areas 4 and 5 localized further south. Virtually no metallic items were documented: just an amorphous element and a large slag. The discovery of many lithics (including some blades) to the north of Area 6 is worth noting. They appear near the limit with Area 7. The typology and the raw material are the same as in 
Burial Site 2. As it occurred in this latter place, the cherts have a dull, whitish, powdery look, which is caused by the strongly acidic soils. The corrosion of calcium is extreme even in recent sites: in the surface layer of Area 6 there are remains of a late $19^{\text {th }}$ - early $20^{\text {th }}$ century occupation, with whiteware, cast iron pots and seashells. Despite their recent date, the shells are almost pulverized, having lost most of their calcium. The same chemical process, in turn, favoured the good preservation of iron, because the dissolved calcium mixed with the silica and formed a sort of cement around metallic artefacts.

The centre of the burial site seems to have been what we identified as Area 7 . Area 7 is destroyed in about $80 \%$ of its total surface. The beginning of Area 7 is marked by the increasing concentration of pottery scatters and the appearance of the first metallic items. The limit with Area 8 is more or less conventional: on the one hand, we chose a cut made by the diggers that runs from east to west. On the other hand, Area 8 provided less finds than Area 7. Although it is true that Area 8 is the least affected by the diggers, it is also true that in the profiles left by the machines there are fewer artefacts than in Area 7. The latter was probably the centre of the burial area, where the number of graves and votive pits was higher and the accumulation denser. Out of 10 tombs located in situ, 8 turned up in Area 7. The pottery scatters in Area 7 are also more numerous and the density of sherds higher. The whole surface is literally carpeted with broken pots: where the rain has opened creeks, thick layers of sherds are visible (FIGURE 10): this proves that, apart from a burial site, there was a settlement on top of (and probably around) the tombs. The stratigraphic profiles left by the diggers were badly eroded by the rains, but some features could be glimpsed, including pits and a feature made of white quartz pebbles (marked as P in the map, figure 9) (FIGURE 11). Pebble pavements have been recorded in several early Carboneras sites in Bioko (Martín del Molino 1965: 17), although some of them appear to be natural. This is probably not a pavement, given its small dimensions (maybe a base of some kind), but it does not look natural, either. Another lithic scatter composed of chert blades and flakes appeared near the northwestern limit of Area 7. 


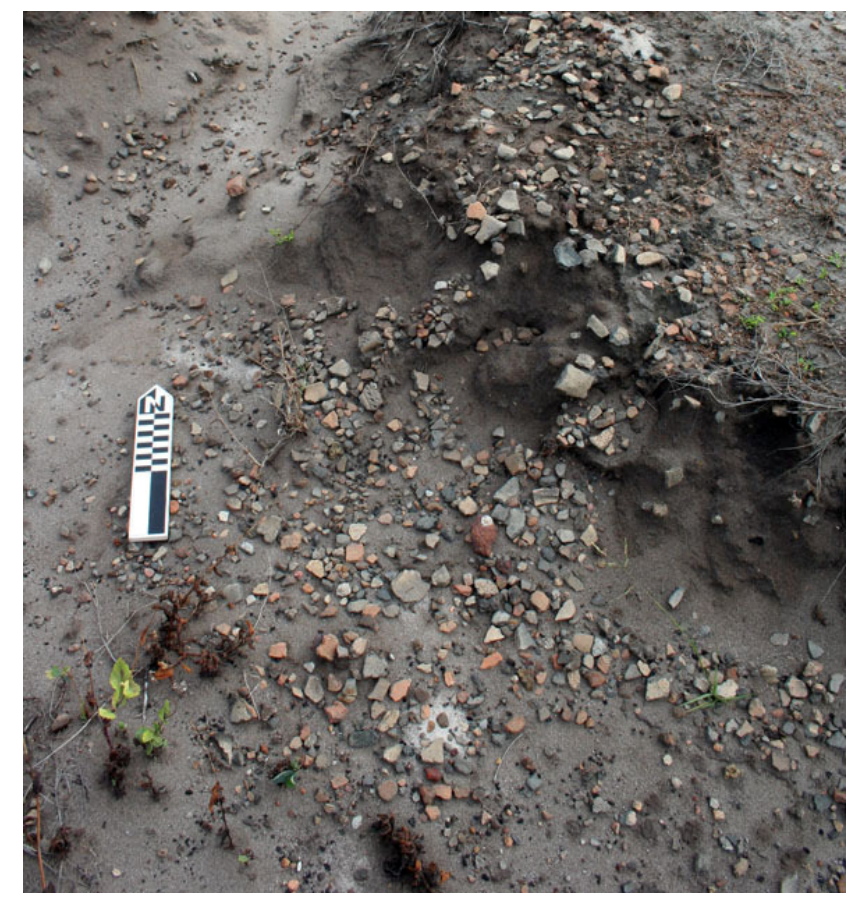

Figure 10 (left): thousands of pottery sherds exposed by the action of heavy rains in BS 3.

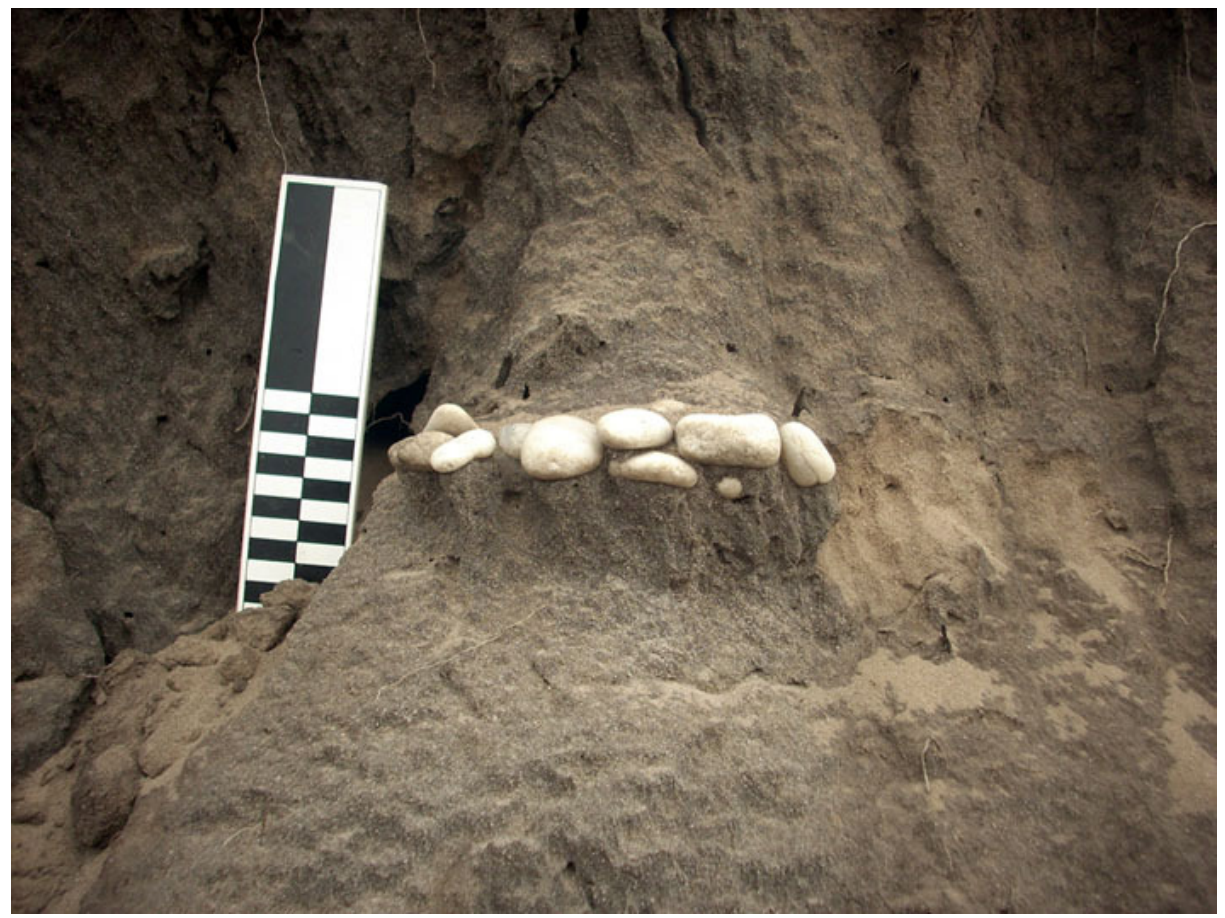

Figure 11 (right): part of a pebble pavement exposed in a profile left by the diggers.

Apart from the iron implements located in the burial deposits, a big flat axe or hoe turned up near the limit with Area 6 (FIGURE 12). We will describe the burials in detail later. Regarding pottery, there is a great diversity of decorative patterns and designs, including incision, simple impression and roulette impression. The pointed, thickened 
rims that we recovered from Burial Site 1 where recorded here as well. As in BS1 and BS2, there are materials that can be attributed to the Late Iron Age (FIGURE 13) and others belonging to the Early Iron Age (FIGURE 14 and 15). As in BS2, pottery from the Early Iron Age is more abundant than that of the later period: very few prehensile buttons and pedestalled bases and no diamond freezes were recorded. One of the profiles that we cleaned in this area allowed us to see the stratigraphic depth and diverse layers of the site and suggests the possibility that Areas 6-8 might have been occupied in more than one period (cf. Figure 23). Unfortunately, no diagnostic materials appeared during the cleaning of the cut, except for the pot from Deposit 3 (see below).

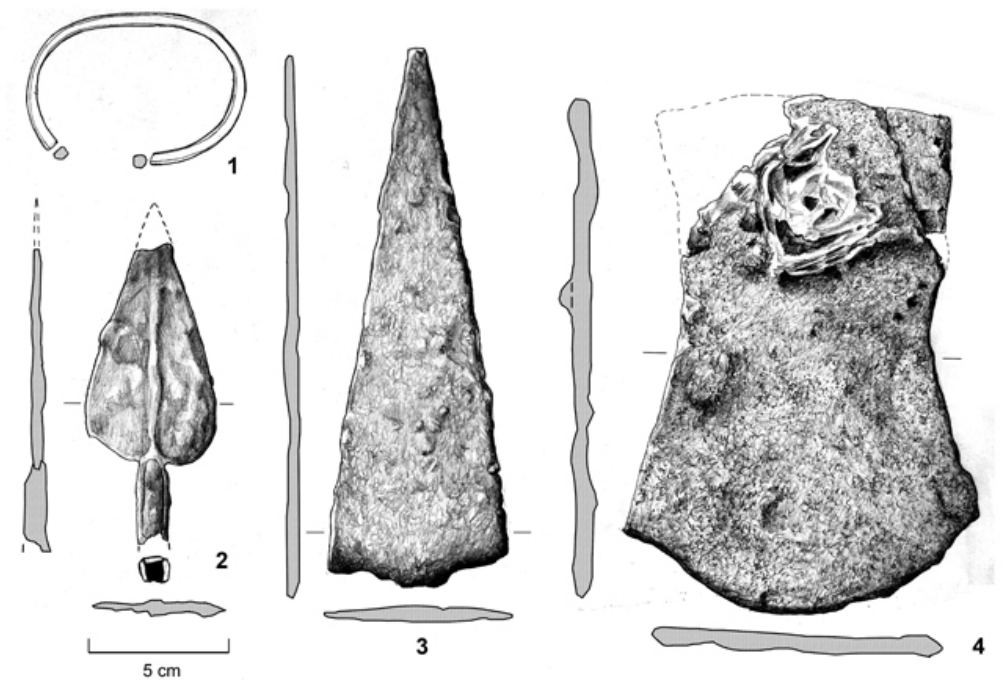

Figure 12 (above). Isolated metallic finds from BS 3. 1-3: Area 8; 4: Area 7.
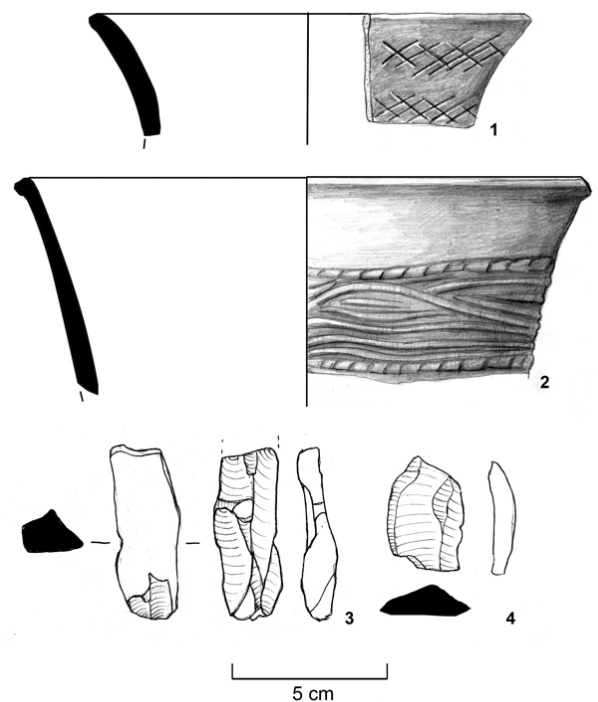

Figure 13 (left). Pottery and lithics from BS 1, Area 7. 

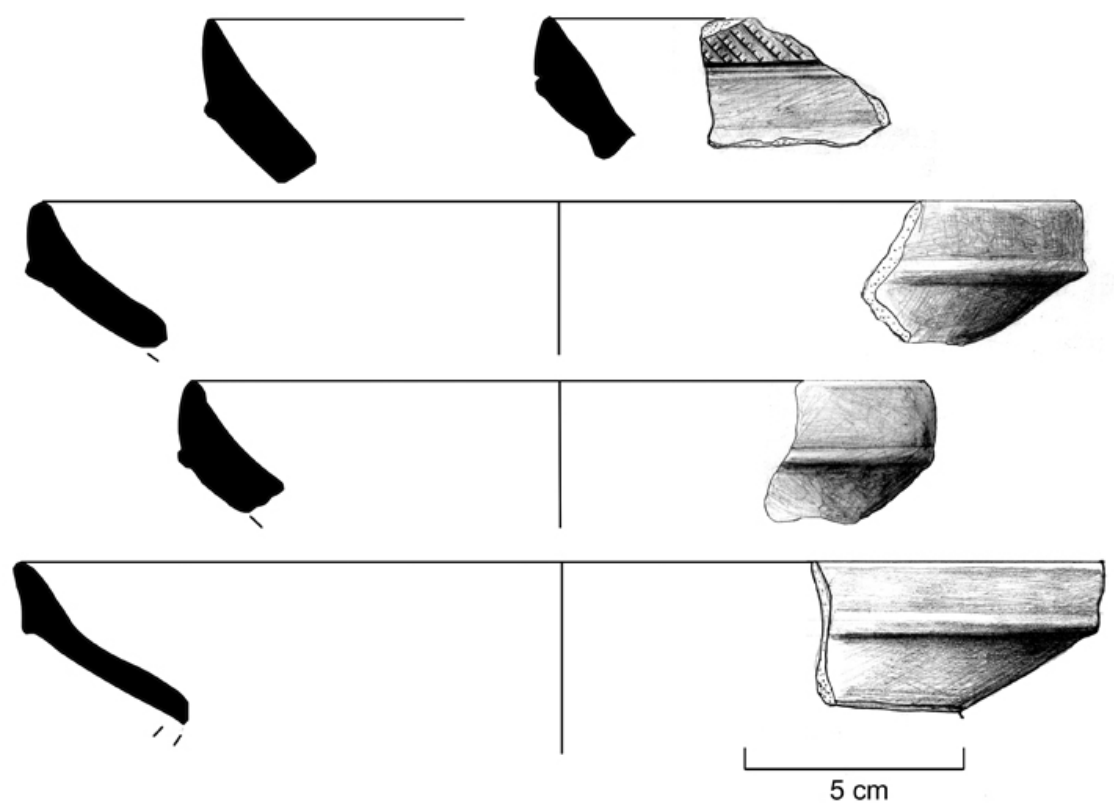

Figure 14. Decorated rims from BS 3 (Areas 6 and 7).

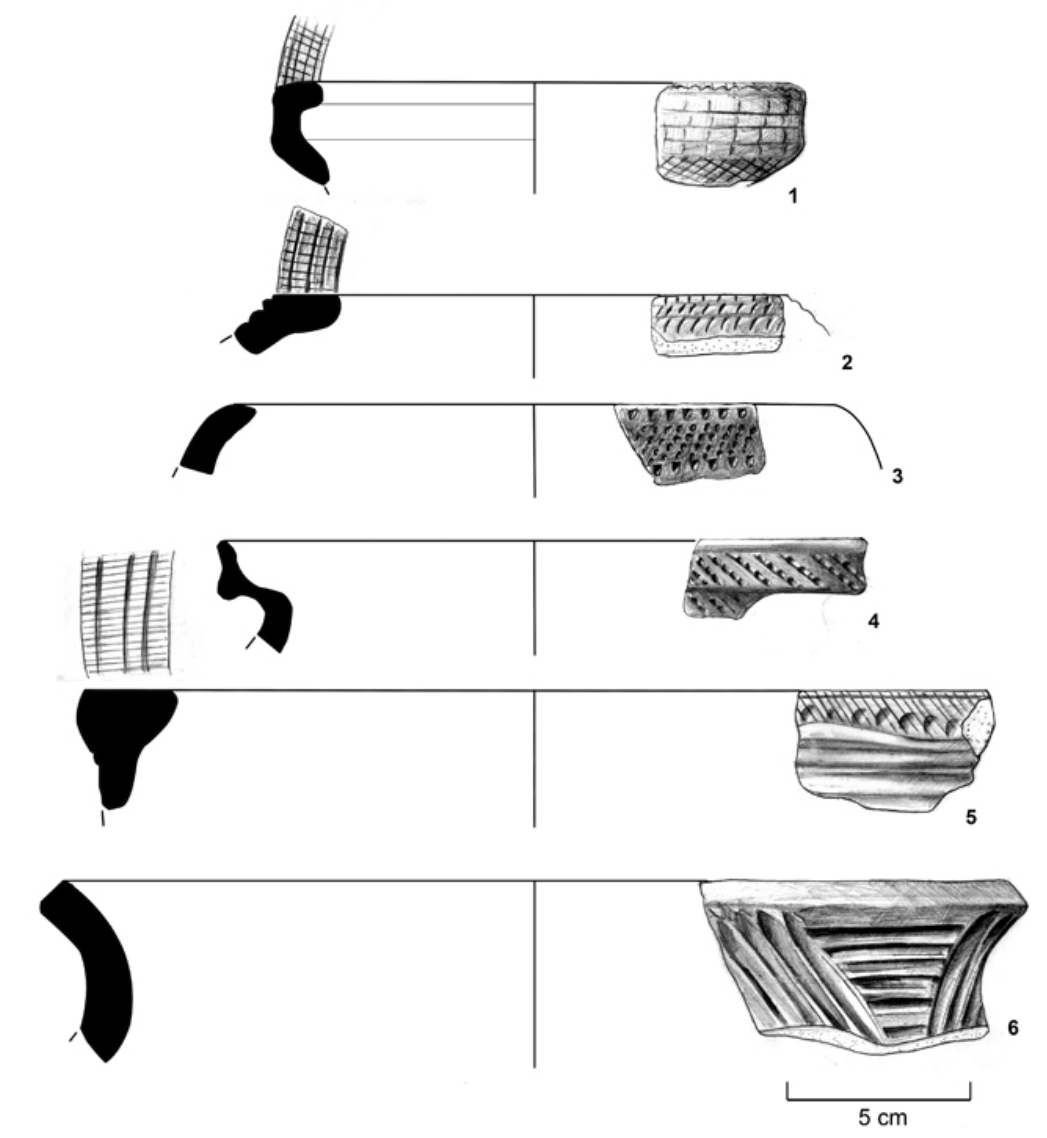

Figure 15. Pointed rims from BS 3 (Areas 6 and 7). 
Area 8 does have a later occupation, but a historical one $\left(19^{\text {th }}\right.$ century). We have found iron cast pots, white ware and transfer ware and a polychrome glass bead. The historical occupation did not touch the prehistoric levels underneath. The Iron Age pottery of Area 8 is similar to the other two. We discovered here a well preserved spearhead with central spine; a long, triangular metal artefact that might be some sort of ceremonial or votive spearhead, and the only example of copper object recovered during our survey (Figure 12, number 1): a bracelet. It could be an import from a copper-artefact producing area, such as southern Nigeria. Two intact burials appeared in one of the profiles left by the diggers in Area 8. It is necessary to say that the cuts in the dune in Area 8 are less clean and vertical than those in Area 7, because the sand has slipped down in greater quantity: other tombs might have been covered again. One of the burials that we recorded had a poorly preserved globular pot and the other one was composed of a single almost complete, but undiagnostic pot (no rim, no decoration), which was lying on its bottom and an iron bracelet. From surface finds, it gave us the impression that there were other similar deposits nearby but we could not check it due to lack of time.

\section{The burials of Area 7 (BS 3)}

Out of eight burials (deposits) identified in Area 7 during our survey, only three provided a good stratigraphic context. The others were too much affected by erosion or the collapse of the walls where they were embedded to be recorded properly.

\section{Deposit 1.}

This burial context was the only one not to be found embedded in an earth wall left by the diggers. It appeared on the surface of the part of Area 7 which had not been touched by the machines. This part of Area 7 is crossed by a path connecting the runway and an isolated hut. The path is sometimes used by vehicles that had gradually eroded the soft humic soil and exposed the archaeological deposits underneath. Rain and wind swept away the sand that covered Deposit 1 and allowed us to find it. Fortunately, the iron objects that composed this hoard were heavy enough not to be easily displaced. It seems that they are reasonably in situ (FIGURE 16). Around the deposit, a large amount of extremely fragmented pottery not related to the grave turned up. They were likely from the upper layer(s) covering the deposit. The deposit was composed of six flat hoes of two different types (3 pear-shaped and 3 hourglass- or double-diamond-shaped), 
fragments of at least two more hoes, and over 40 rings and fragments of rings that were part of two or more composite bracelets (rather than anklets, given the size) (FIGURE 17). The hourglass-shaped hoes are in all likelihood votive/ritual elements, not utilitarian (cf. Meister 2010: 243). In 2010, during a short visit to the place by one of us (LPG), an axe was discovered in the same place where we had documented Deposit 1. It is of the same type of those discovered in Deposit 2c.

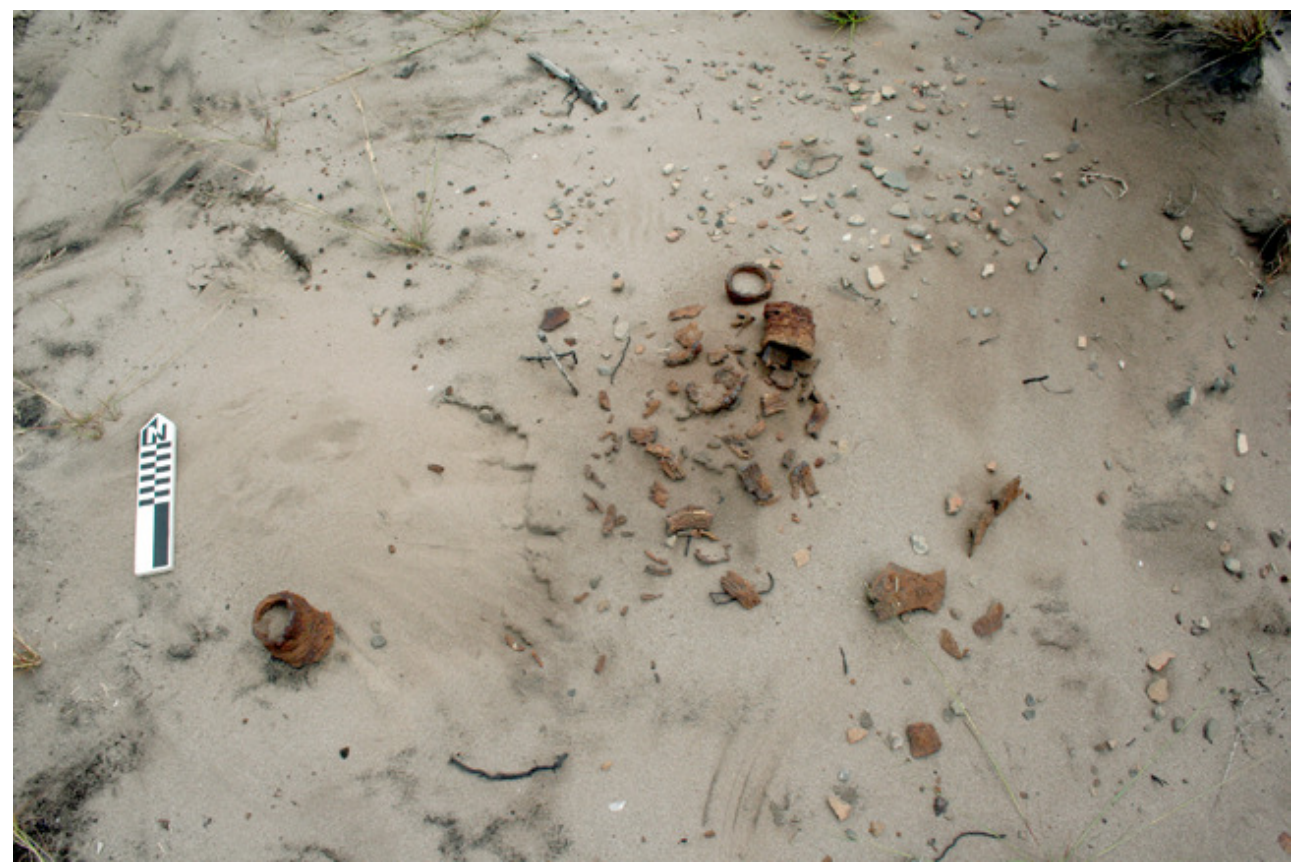

Figure 16. Deposit 1 from BS 3 at the moment of its discovery.

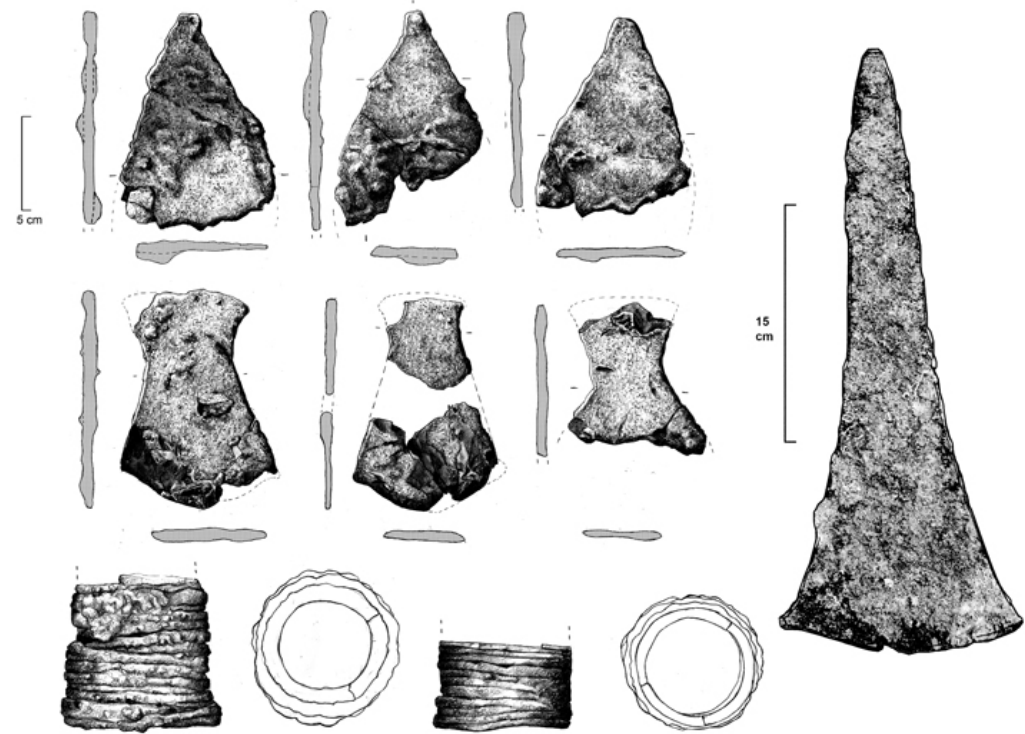

Figure 17. Materials from Deposit 1 - BS 3. 


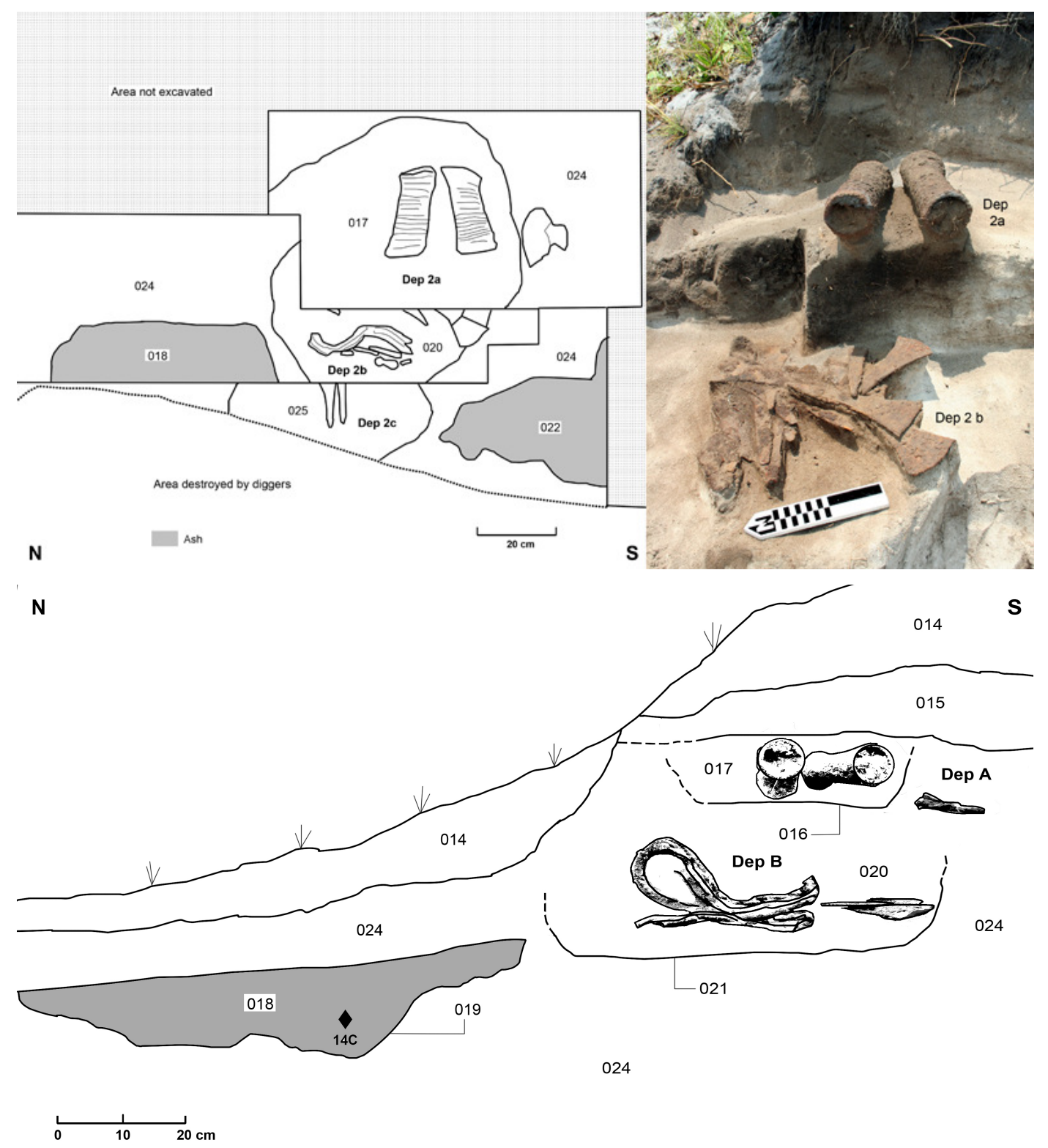

Dep C

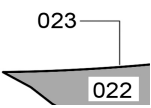

Figures 18 and 19. Plan and oblique cut of Deposits $2 a-c$.

\section{Deposit 2.}

This was by far the most spectacular of all ritual deposits identified so far. It is in fact three deposits, that we have named Deposit $2 \mathrm{a}, 2 \mathrm{~b}$ and $2 \mathrm{c}$, from top to bottom (FIGURE 18 and FIGURE 19). Paradoxically, the first to be discovered was Deposit 2c, because it was protruding from the earth wall left by the diggers that we were surveying. We cleaned the profile and discovered that the deposits were situated one on top of the other, 
but also obliquely, dipping from east to west. This explains that the deeper deposit was also the one most exposed. Deposit 2c was composed of two big axes which were lying flat, one on top of the other (FIGURE 20). One of the axes was decorated with parallel vertical lines. Decorated axes are common in Central Africa and they are invariably linked to political status and religious functions (cf. Childs and Dewey 1996:157-158).

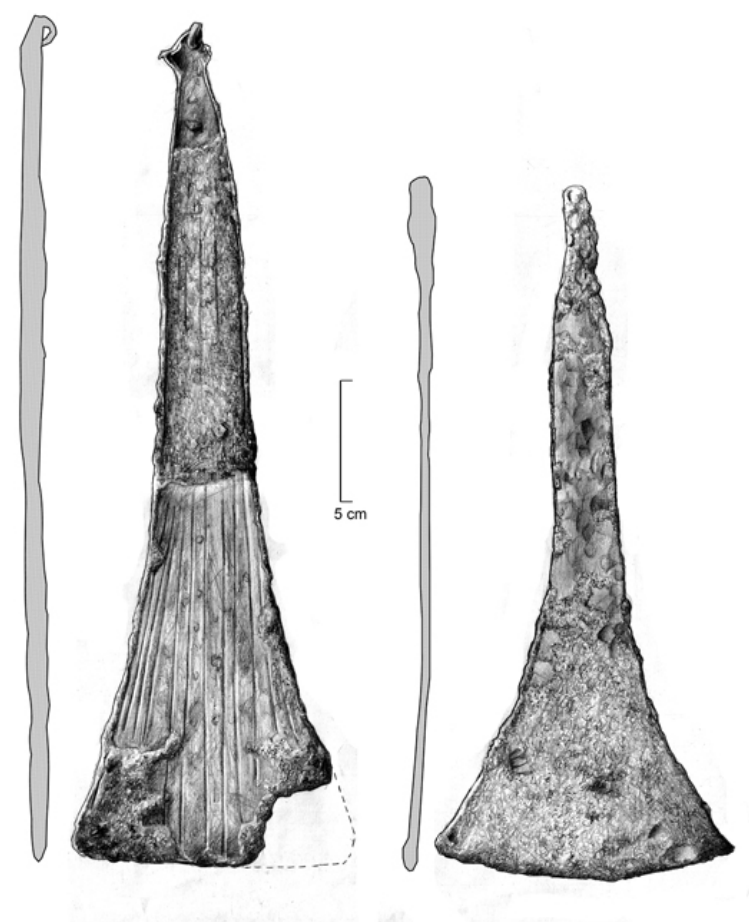

Figure 20. Axes from Deposit $2 c-B S 3$.

Unfortunately, the stratigraphic context of Deposit 2c was much altered by the action of the diggers first and the erosion of the cut later. It was not possible to document the feature to which the deposit was associated. This was not the case with deposits $2 \mathrm{a}$ and 2c. Despite the sliding of the wall, it was possible to record every item in situ. The stratigraphy, however, was damaged by the construction works, a path on the northern side, and the action of roots (this area was cultivated in the recent past). The burials here were closer to the surface than those in the area of deposits 3 to 5 . The sequence of deposition, however, and the delimitation of each hoard is very clear.

All three deposits were placed in shallow pits, filled with organic, light brownish soil. The pits, or rather holes, were dug in the same matrix: the white, thin sand of a fixed dune (stratigraphic unit 024), which has the same texture, colour and compactness all throughout the sequence (unlike in Deposit 3, see below). This leads us to think that the deposits were all made very close in time and the surface of the dune was not left 
exposed at any moment (a situation which would have changed the texture and chemical composition of the soil). That is, every time a deposit was made, it was immediately covered by the same white sand of the dune by those who have dug it. Along with the three pits with artefacts, two other shallow pits were discovered (marked grey in the profile). They have a roughly rectangular shape and are oriented N-S. These pits were filled with ash and minute fragments of charcoal, including some charred oil palm endocarps. One of them (in stratigraphic unit 018) was radiocarbon dated to cal. 430640 AD (Beta 268458: 1510+-40 BP).

Deposit 2a (FIGURE 21) yielded two perfectly preserved anklets made of 35 iron rings each; an unidentified metal object, perhaps a hoe; a double iron ring which might have been used as a hairgrip (as the one collected in Burial Site 1); a small pentagonal iron artefact, probably a currency element; two double-diamond flat iron objects and a bundle of iron artefacts which are similar to those identified as specialpurpose currency in Cameroon (Meister and Eggert 2008; Meister 2010).

Deposit 2b (FIGURE 22) is immediately below. It furnished 15 axes, two spearheads with long tang, two spoons, a bundle of iron rods, and a small triangular flat iron artefact ended in a circle (somewhat similar to Meister and Eggert 2008: fig. 6, 3).

Given the difference between these two assemblages and the nature of the artefacts, it seems tempting to think that Deposit 2a belongs to a woman and Deposit $2 \mathrm{~b}$
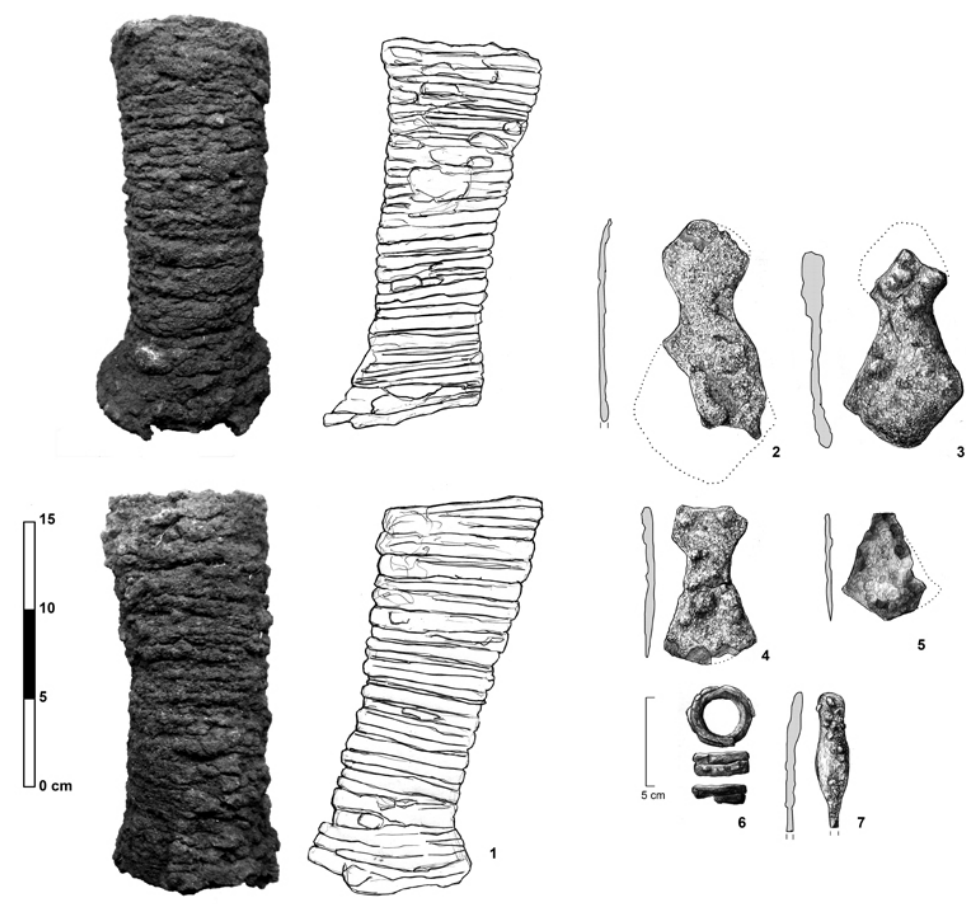

to a man, both of high status.

Figure 21. Objects found in Deposit $2 a$. 

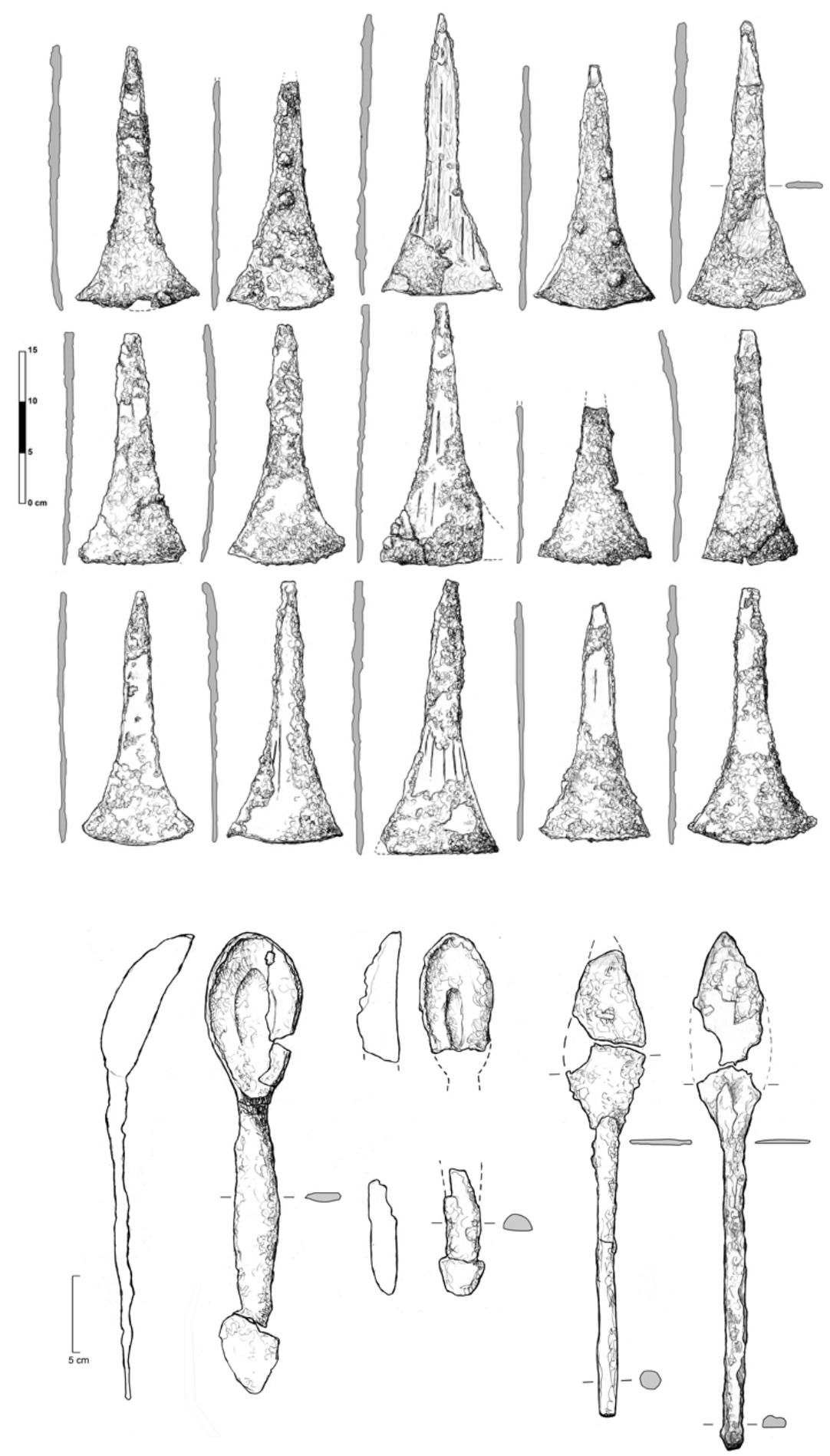

Figure 22a and b: axes from Deposit $2 b$ and spoons and spearheads from the same deposit. 


\section{Deposit 3.}

This is the deposit whose stratigraphy could be better recorded (FIGURE 23), thanks to the fact that only a relatively small part of the pot protruded from the wall. The stratigraphic sequence is more complex than it might look at first sight.

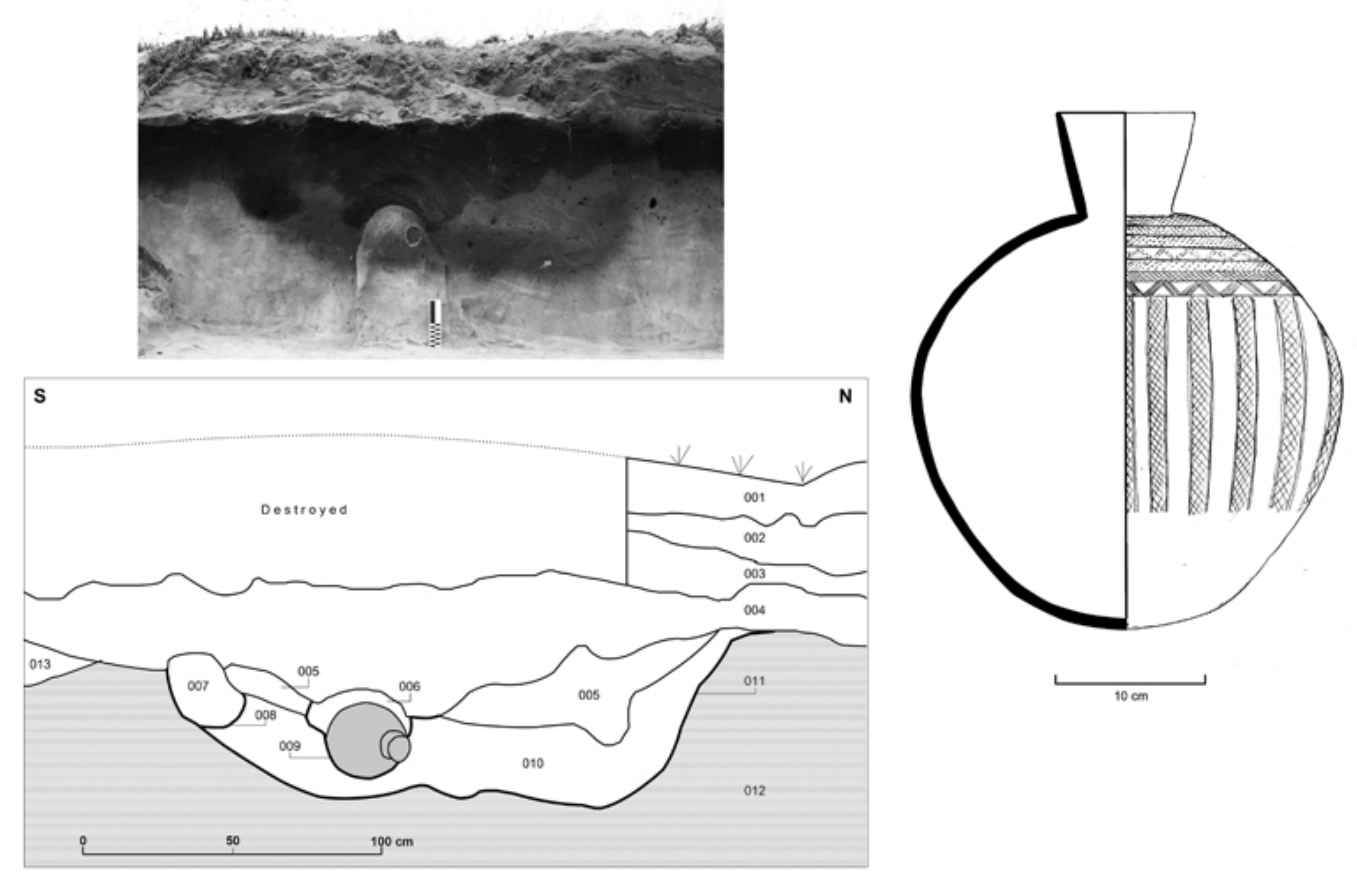

Figure 23. Deposit $3-B S 3$.

First, the dune (stratigraphic unit 012) was dug (011) to make a pit 2 meters long in its upper part and 1 meter long at the bottom. The sides of the pit slope down gently to the bottom. The pit was filled later with two layers of soil, the one on the bottom darker and more organic (010), the one on the top lighter and sandier (005). This deposit was later re-excavated (009) to insert a medium-sized pot, lavishly decorated with incised vertical bands forming reticules, chevrons and impressed dots. The pot was covered by a richly organic layer of black soil (006). Probably at the same time, the original deposit was also dug further to the south (008) and, again, the resulting pit filled with black, organic soil (007). This time no offering was placed in the pit, although we think that something organic could have been, in fact, offered, which has consequently disappeared. Everything was later covered by a layer of dark-brown soil, very organic and with many small fragments of pottery (004), mostly undiagnostic. From stratigraphic unit 004 several radiocarbon samples were taken. One of them was dated to 410-590 cal. AD (Beta 264859: 1560+-40 BP), which gives a date ante-quem for the formation of 
Deposit 3. Two other strata (apart from the humic layer on top) cover 004. The soil is lighter and sandier in both cases and they have yielded scarce finds, although the surface preserved of 002 and 003 is small. We would argue that the two later pits excavated in the grave-and the pot deposited in one of them-are evidence of secondary ritual activity related to a burial, of which there are many ethnographic examples in Africa. The elongated shape of the grave is homologous to those documented in Akonétye (Meister and Eggert 2008: fig. 7). The size is also similar. The reopening of a pit for further deposition has been documented at Bwambé in Cameroon (Eggert et al. 2006: 280), which is dated to the second half of the $1^{\text {st }}$ millennium BC.

\section{Deposit 4.}

A medium-sized globular pot of light ochre colour originally deposited in a pit. The wall had collapsed and the pot was fragmented. Traces of the original pit could be glimpsed from the hole left on the wall and the darker soil, but the overall context was extremely degraded. It is very close to Deposit 3 and 5, which are also pots buried in pits. To the south of Deposit 4 there are several holes that in all likelihood represent traces from pits which have had pots inside.

\section{Deposit 5.}

A single bottle, perfectly preserved, from a pit (FIGURE 24). The stratigraphy could not be recorded, because the profile collapsed immediately after the extraction of the pot by our local assistant. The bottle has a globular body, straight neck and incised bands as decoration. No other finds were associated to the bottle.

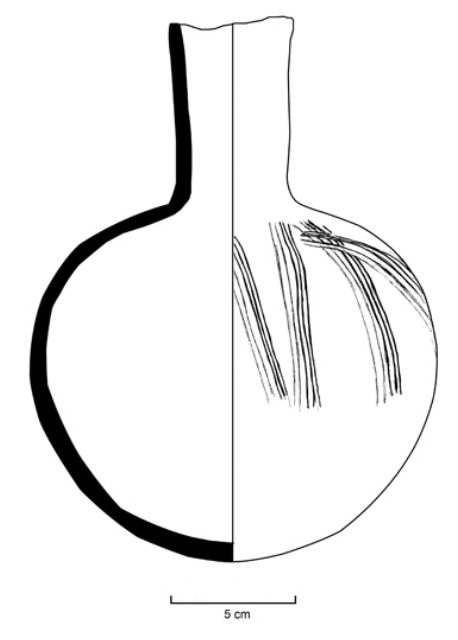

Figure 24. Bottle from Deposit 5.

\section{The burial sites of Mandji in its regional context}

The burial sites of Mandji are extraordinarily similar to those recently discovered in southern Cameroon, from the point of view of the artefacts deposited in graves and pits and the contexts of deposition. Regarding the artefacts, the same types of objects appear: axes, hoes, 
spearheads, special-purpose currency, bracelets, anklets and spoons (Meister 2008). Moreover, the artefacts are quite similar from a typological point of view. The big axe of Akonétye (Meister and Eggert 2008: fig. 6,6) is exactly of the same type as the axes from Deposit 1, Deposit 2b and 2c (BS 3), although the specimens from Mandji show a different decoration. From the photo of Gouem Gouem and Lavachery's presentation, it seems that the axes we have found in Burial Site 3 are also very similar to those from one of the richest graves at Mpoengu (Gouem Gouem and Lavachery 2006). Bracelets and anklets are very common both in Cameroon and Mandji (Meister 2010: 243). The special-purpose currency is also typologically homologous in all these sites, with a tendency towards hourglass, double-diamond and spindle shapes (Meister 2010: 240, 243). The sharing of similar, even identical artefacts, between southern Cameroon and Mandji might indicate that there existed other, less material, things that were being shared as well (customs, practices, ideas).

Similarities are not restricted to objects, but can also be seen in rituals. Equivalent features and contexts appear along the coast between Cameroon and Gabon. It seems, for instance, that the duality of deposits present in BS3 is also documented in Akonétye and Mpoengu: there are pits with complete pots alone and proper graves that delivered the majority of iron artefacts (Gouem Gouem and Lavachery 2006; Meister and Eggert 2008; Meister 2010). Pits themselves are another example of what looks like a much extended tradition in Cameroon (Lavachery et al. 2005; Eggert et al. 2006), Equatorial Guinea (Martín del Molino 1965: 11, 24-28) and Gabon (Jézégou 1991). However, the pits documented in Mandji so far are rather shallow, in comparison to the deep pits known in southern Cameroon or Bioko, which attain three or more metres. The elongated shape and size of the graves located in Cameroon (Meister 2010) are similar to our Deposit 3. Also, the arrangement of metal objects in Mandji's graves brings to mind the contexts of southern Cameroon: the special-purpose currency tied in bundles (Akonétye: Meister and Eggert 2008; Lobethal: Meister 2008) or the accumulation of axes (Mpoengu: Gouem Gouem and Lavachery 2006; Meister 2008). Thus far, however, we have not documented inverted pots: this could be a ceremonial practice that was more geographically restricted (Meister 2010: fig. 9). Also, the very fact of accumulation itself is interesting: iron was undoubtedly perceived as something valuable and iron hoarding (actually hoarding in general) only started when iron technology was perfectly mastered (Meister 2010: 247) 
Unlike in Cameroon, finds of iron artefacts have been rare in Gabon so far. The only remarkable assemblage is a group of 10 flat axes fortuitously discovered near Libreville (Clist and Farine 1990), of which four could be studied. Typologically, they are quite different from the objects retrieved in Mandji. Although the spindle shape of two of them is somewhat redolent of some our artefacts, differences are important as well. In any case, if the hoard is from the Late Iron Age-as Clist and Farine (1990) argue-it would at least show the continuity of a ritual practice and the symbolic relevance of certain iron objects.

There are sites in Gabon, however, that, although yielding few metallic objects, bear strong resemblances with Mandji: this is the case of Sablières, in the Gabon estuary (Peyrot et al. 1990). The points of similarity are many: in the first place, the location. The burial site of Sablières is located along the axis of a dune, parallel to a beach. The "cordon dunaire" is characterized by a savannah-like environment (Clist 1995: 168), in contrast to prevailing mangroves and rainforests, a situation that parallels that of Mandji, where burial sites occupy grasslands over fixed dunes. The size of Sablières is difficult to gauge, because of the destructions produced by sand extraction, but the distribution of the finds shows that it was a rather large site, like those of Mandji: two of the loci are separated 150 meters. Few iron items were located in Sablières: an axe and a blade (maybe from another axe or a hoe) (Clist 1995: 168). However, the pots, as we have already pointed out, are extraordinarily similar in shape and decoration to those recovered at the cemeteries of Mandji. The depositional context is also homologous: 13 complete vessels turned up in Sablières, buried directly in the sand. Four of the pots appeared grouped together and buried $80 \mathrm{~cm}$ deep in the fixed dune, a context equivalent perhaps to Burial Site 1 in Mandji and Campo in Cameroon (Meister 2008). Peyrot et al. (1990: 491) interpret this assemblage as evidence of a burial context ("nécropole": Clist 1995: 167-168). There is a single radiocarbon date, comprised between 715-1016 cal. AD (Gif 6426, 1150 +- 60), that is, immediately later than the deposits dated in Mandji. Complete, decorated pots as those of Sablières and presumably in equivalent contexts have turned up in other sites around the estuary, with radiocarbon dates that overlap —at least partially_with those of Mandji: Remboué (546-860 cal. AD), Malékou (437-1021 cal. AD) (Clist 1995: 181) and, further to the south, in the Ogouué estuary, Mbilapé (6 ${ }^{\text {th }}$ century AD: Jézégou 1991: 205). With these dates and contexts, Clist proposes an Early Iron Age group for the Gabon estuary 
labelled "Groupe II", which is comprised between 600 and 1000 AD. The data from Mandji suggest a revision of this chronology.

\section{Conclusions}

Until the last few years, the main part of our information for the Iron Age in Equatorial Africa was composed of pottery assemblages, which offered a very fragmented and varied panorama (Jézégou 1991; Clist 1989; Wotzka 1995), with many (often contemporaneous) distinct typological groups. These groups have been equated with cultures, communities or, more safely, technical traditions. The homologous materials and ritual contexts found in southern Cameroon and southern Equatorial Guinea show that, beyond the great local diversity, there were important cultural similarities and possibly similar socio-political processes taking place in a rather large regionprocesses which, so far, seemed absent in the rainforests of Equatorial Africa.

Considering the finds from southern Cameroon, Equatorial Guinea and northern Gabon, we could suggest shared cultural elements that span throughout the $1^{\text {st }}$ millennium cal. AD along the coast of those three countries. With the radiocarbon dates at our disposal (Clist 1995; Gouem Gouem and Lavachery 2006; Eggert 2006; Meister and Eggert 2008), we could probably narrow the time span for this tradition to cal. 100 - $850 \mathrm{AD}$, with an early phase documented in Cameroon at the turn of the millennium (Meister and Eggert 2008; Eggert 2010).

One of the interesting points that raise the sites of Mandji and Cameroon is the significance of metallurgy and iron artefacts during the Early Iron Age. The political and symbolic relevance of iron artefacts and ironworking was well known for the last five hundred years in different parts of Sub-Saharan Africa. To mention a few examples: in the impressive Angolan site of Feti, a royal tumulus dated between the $9^{\text {th }}$ and $13^{\text {th }}$ centuries AD, yielded hoes, knifes, arrowheads, spearheads, anvils and hammers (Vansina 2004: 172-173). Likewise, the ruler of Ngoyo, in the Congo, displayed a variety of metallurgical implements and adornments as a fundamental part of his regalia by the end of the $15^{\text {th }}$ century (Bisson 2000: 128-130). Herbert (1993: 134-135) notes the use of axes and bracelets as royal symbols in different parts of West Africa. In Rwanda, the king performed as symbolic acts practical tasks that were crucial to the survival of his people: cultivating the land, ironworking, making fire, hunting, conducting people to war, etc. (Bonte 1991: 67). For the performance he used particular metal implements (hoes, hammers, arrows, spears). Iron and bronze collars, such as 
those discovered in BS1, have been a symbol of leadership in different parts of Central Africa since at least the $15^{\text {th }}$ century. The burial contexts documented in Cameroon and Equatorial Guinea could be interpreted as early evidence of the important role of rituality and prestige goods that makes traditional African politics so characteristic (McIntosh 1999: 12-14, 18). Moreover, the outstanding similarity between the artefacts that have been convincingly identified by Meister (2008) as special-purpose currency and recent traditional elements of bridewealth among the Fang (Guyer 1986) could perhaps indicate that the link between iron, wives and wealth is not a rather recent phenomenon, as some anthropologists think (Guyer 1986: 583), but an ancient one.

In any case, the new archaeological data reveal the existence of another core area for the emergence of inequalities in Sub-Saharan Africa (cf. McIntosh 1999; Connah 2001). Two elements make this new area remarkable: its early dates and its location in the equatorial rainforest belt. The best known examples of chiefdom and state formation processes south of the Sahel were of the late $1^{\text {st }}$ millennium AD onwards: this is the case of the Kisalian culture of southeast Congo (de Maret 1977), the Igbo-Ukwu region of southern Nigeria (Shaw 1970) or the kingdoms of Uganda and Rwanda (Sutton 1993), all of them in the periphery of the equatorial rainforest. With the exception of southern Nigeria and southern Ethiopia, most early complex polities in Africa seemed to have avoided dense rainforests in favour of savannahs, grasslands or dry forests.

In conclusion, the littoral between Cameroon and Gabon offers a new and exciting area of study to explore the emergence and development of inegalitarian polities in Sub-Saharan Africa.

\section{Acknowledgements}

The authors want to thank the Spanish Cultural Centre in Bata for financial and institutional support. Special thanks are due to the director, $\mathrm{M}^{\mathrm{a}}$ Ángeles Díaz Ojeda for her interest in this project. The Equatoguinean authorities facilitated our work and showed a keen interest in the research. We are grateful to Anacleto Oló, cultural counsellor to the presidency, for providing the research permit, and Guillermina Mekuy for her support. We were helped at all times in the field by Agustín Ndong. The inhabitants of Mandji were very helpful and hospitable. We want to thank Santiago Hinestrosa for facilitating our work in the island. We are also grateful to Manfred Eggert and Conny Meister for sending their publications on southern Cameroon and for advice. Thanks are also due to Conny Meister for pointing to us Jane Guyer's important 
article on indigenous currency. Finally, we would like to thank Bernard Clist and an anonymous referee for their valuable comments, which have significantly improved the article. All errors remain our own.

\section{References}

Bisson, M.S. (2000): Precolonial copper metallurgy. Sociopolitical context. En S.O. Vogel, ed.: Ancient African Metallurgy. The sociocultural context. Altamira Press, Walnut Creek, CA: 83-145.

Bonté, P. (1991): To increase cows, God created the King: the function of cattle in Intralacustrine societies. En J.G. Galaty y P. Bonte, eds.: Herders, warriors and traders. Pastoralism in Africa. Westview Press. Boulder, San Francisco, Oxford. 62-86.

Childs, S.T. and Dewey, W.J. 1996. Forging symbolic meaning in Zaire and Zimbabwe. In P.R. Schmidt (ed.): The culture and technology of African iron production. Gainesville: University Press of Florida, 145-171.

Clist, B. 1987. Recherches archéologiques en Guinée Equatoriale: 1985. Nsi 1: 16-17.

Clist, B. 1989. Archaeology in Gabon, 1886-1988. African Archaeological Review 7: 59-95.

Clist, B. 1991. Guinée Équatoriale. In R. Lanfranchi and B. Clist (eds.) : Aux origines de l'Afrique Centrale. Libreville : Centre Culturel Français de l'Afrique Centrale, Centre International des Civilisations Bantu, 161-164.

Clist, B. 1995. Gabon: 100000 ans d'Histoire. Libreville: Centre Culture Français Saint-Exupéry.

Clist, B. 1998. Nouvelles données archéologiques sur l'histoire ancienne de la GuinéeEquatoriale. L'Anthropologie 102(2): 213-217.

Connah, G. 2001. African civilizations. An archaeological perspective. Cambridge: Cambridge University Press.

de Maret, P. 1977. Sanga: new excavations, more data, and some related problems. Journal of African History 18: 321-337.

de Maret, P. and Clist, B. 1987. Mission de fouilles 1987 en Guinée-Equatoriale insulaire. Nsi $2: 32-35$.

Edwards, D.N. 2007. The archaeology of Sudan and Nubia. Annual Review of Anthropology 36: 211-228. 
Eggert, M.K.H. 1992. The Central African rainforest: historical speculation and archaeological facts. World Archaeology 24(1): 1-24.

Eggert, M.K.H. 1993. Central Africa and the archaeology of the equatorial rainforest: reflections on some major topics. In T. Shaw, P. Sinclair, B. Andah, A. Okpoko (eds.): The archaeology of Africa. Food, metals and towns. One World Archaeology 20. London and New York: Routledge, 289-329.

Eggert, M.K.H., Höhn, A., Kahlheber, S., Meister, C., Neumann, K. and Sweitzer, A. 2006. Pits, graves and grains: archaeological and archaeobotanical research in Southern Cameroon. Journal of African Archaeology 4(2): 273-298.

Gouem Gouem. B. and Lavachery, P. 2006. First village communities in the Southern littoral region of Cameroon. Paper presented at the Society of Africanist Archaeologists Meeting, Calgary 22-26 June 2006. Presentation available at: http://cohesion.rice.edu/CentersAndInst/SAFA/emplibrary/GouemGouem,B.Lava chery,P.SAfA2006.pdf

Guyer, J.I. 1986. Indigenous currency and the history of marriage payments. A case study from Cameroon. Cahiers d'Études Africains 104: 577-610.

Herbert, E.W. 1993. Iron, gender and power. Rituals of transformation in African societies. Bloomington: Indiana University Press.

Holl, A. 2009. Early West African metallurgies: new data and old orthodoxy. Journal of World Prehistory 22: 415-438.

Jézégou, M.-P. 1991. Gabon. In R. Lanfranchi and B. Clist (eds.): Aux origines de l'Afrique Centrale. Libreville: Centre Culturel Français de l'Afrique Centrale, Centre International des Civilisations Bantu, 203-207.

Lanfranchi, R. and B. Clist (eds.), 1991. Aux origines de l'Afrique Centrale. Libreville : Centre Culturel Français de l'Afrique Centrale, Centre International des Civilisations Bantu.

Lavachery, P., MacEachern, S., Bouimon, T., Gouem Gouem, B., Kinyock, P., Mbairoh, J., Mbida, C. and Nkonkonda, O. 2005. Cultural heritage management in Central Africa: regional survey on the Chad - Cameroon oil pipeline. Antiquity 79. Project Gallery. http://antiquity.ac.uk/Projgall/maceachern/

Martín del Molino, A. 1965. Secuencia cultural en el neolítico de Fernando Poo. Trabajos de Prehistoria 17: 9-53.

Martín del Molino, A. 1989. Prehistoria de Guinea Ecuatorial, Africa 2000 10-11: 4-21. 
McIntosh, S.K. 1999. Pathways to complexity: An African perspective. Beyond chiefdoms: pathways to complexity in Africa. Cambridge: Cambridge University Press, 1-30.

Meister, C. 2007. Recent archaeological investigations in the tropical rain forest of South-West Cameroon. In J. Runge (ed.): Dynamics of forest ecosystems in Central Africa during the Holocene. Past - present - future. Leiden: Taylor \& Francis/Balkema, 43-57.

Meister, C. 2010. Remarks on Early Iron Age burial sites from Southern Cameroon. African Archaeological Review 27(3): 237-249.

Meister, C. and Eggert, M.K.H. 2008. On the Early Iron Age in Southern Cameroon: The sites of Akonétye. Journal of African Archaeology 6(2):

Mercader, J. and Martí, R. 1999. Middle Stone Age sites in the tropical forests of Equatorial Guinea. Nyame Akuma 51: 14-24.

Nerín, G. forthcoming. La esclavitud en Guinea Ecuatorial. Islas de conocimiento, un océano de ignorancia y brumas que lo esconden todo.

Oslisly, R. 2006, Les traditions culturelles de l'Holocène sur le littoral du Cameroun entre Kribi et Campo, In Grundlegungen Beiträge zur europäischen und afrikanischen Archäologie für Manfred K.H. Eggert (ed. H.-P. Wotzka): pp 303317. Tübingen: Francke Verlag.

Panyella, A. y Sabater, J. 1959. El poblado neolitico de Playa Carboneras (Fernando Poo). Africa (Madrid) 205: 5-9.

Perramón, R.H. 1968. Contribución a la prehistoria y protohistoria de Río Muni, Publicaciones del Instituto Claretiano de Africanistas, 26. Santa Isabel: Instituto Claretiano de Africanistas.

Perrois, L. 1985. Ancestral art of Gabon: from the collections of the Barbier-Mueller Museum. Geneva: The Museum.

Peyrot, B., Clist, B. and Oslisly, R. 1990. Le gisement des "Sablières" de Libreville: étude géomorphologique et archéologique d'un site préhistorique de l'Estuaire du Gabon, L'Anthropologie 94(3): 483-498.

Shaw, T. 1970. Igbo-Ukwu: an account of archaeological discoveries in eastern Nigeria. London: Institute of African Studies, University of Ibadan.

Sutton, J.E.G. 1993. The antecedents of the interlacustrine kingdoms. Journal of African History 34: 33-64. 
Tessman, Günter. 2003 [1913] Los pamues. Monografía etnológica de una rama de las tribus negras del África occidental. Alcalá de Henares: Publicaciones de la Universidad de Alcalá.

Unzueta y Yuste, A. 1945. Islas del Golfo de Guinea (Elobeyes, Corisco, Annobón, Príncipe y Santo Tomé). Madrid: Instituto de Estudios Políticos.

Van Noten, F.L. (with contribution by D. Cahen, P. de Maret, J. Moeyersons and E. Roche) 1982. The Archaeology of Central Africa. Graz: Akademische Drück und Verlagsanstalt.

Vansina, J. 2004. How societies are born: governance in West Central Africa before 1600. Charlottesville, London: University of Virginia Press.

Wotzka, H.P. 1995. Studien zur Archäeologie des Zentral-Afrikanischen Regenwaldes: Die Keramik des inneren Zä̈re-Beckens und ihre Stellung im Kontext der BantuExpansion. Africa Praehistorica 6. Köln: Heinrich Barth Institut. 